\title{
Greenland Ice Sheet surface mass balance 1870 to 2010 based on Twentieth Century Reanalysis, and links with global climate forcing
}

\author{
Edward Hanna, ${ }^{1}$ Philippe Huybrechts, ${ }^{2}$ John Cappelen, ${ }^{3}$ Konrad Steffen, ${ }^{4}$ Roger C. Bales, ${ }^{5}$ \\ Evan Burgess, ${ }^{6}$ Joseph R. McConnell, ${ }^{7}$ Joergen Peder Steffensen, ${ }^{8}$ Michiel Van den Broeke, ${ }^{9}$ \\ Leanne Wake, ${ }^{10}$ Grant Bigg, ${ }^{1}$ Mike Griffiths, ${ }^{11}$ and Deniz Savas ${ }^{11}$ \\ Received 10 June 2011; revised 28 September 2011; accepted 3 October 2011; published 28 December 2011.
}

[1] We present a reconstruction of the Greenland Ice Sheet surface mass balance (SMB) from 1870 to 2010, based on merged Twentieth Century Reanalysis (20CR) and European Centre for Medium-Range Weather Forecasts (ECMWF) meteorological reanalyses, and we compare our new SMB series with global and regional climate and atmospheric circulation indices during this period. We demonstrate good agreement between SMB annual series constructed from 20CR and ECMWF reanalyses for the common period of overlap and show statistically significant agreement of long-term modeled snowfall with ice-core-based accumulation data. We analyze variations in SMB for the last 140 years and highlight the periods with significantly increased runoff and decreased SMB since 1870, which have both been enhanced in the period since 1990, as well as interannual variations in SMB linked to Greenland climate fluctuations. We show very good agreement of our SMB series variations with existing, independently derived SMB series (RACMO2) variations for the past few decades of overlap but also a significant disparity of up to $\sim 200 \mathrm{~km}^{3} \mathrm{yr}^{-1}$ in absolute SMB values due to poorly constrained modeled accumulation reflecting a lack of adequate validation data in southeast Greenland. There is no significant correlation between our SMB time series and a widely referenced time series of North Atlantic icebergs emanating from Greenland for the past century, which may reflect the complex nature of the relationship between SMB and ice dynamical changes. Finally, we discuss how our analysis sheds light on the sensitivity and response of the Greenland Ice Sheet to ongoing and future global climate change, and its contribution to global sea level rise.

Citation: Hanna, E., et al. (2011), Greenland Ice Sheet surface mass balance 1870 to 2010 based on Twentieth Century Reanalysis, and links with global climate forcing, J. Geophys. Res., 116, D24121, doi:10.1029/2011JD016387.

\section{Introduction}

[2] The Greenland Ice Sheet (GrIS) is especially vulnerable to ongoing climate change, encompassing relatively lowlatitude (for such an ice mass), warm-in-summer regions that have been warming strongly by $\sim 2^{\circ} \mathrm{C}$ since the early $1990 \mathrm{~s}$ [Hanna et al., 2008] and are predicted to further warm by between 2 and $12^{\circ} \mathrm{C}$ during the present century [Gregory et al., 2004]. The GrIS has been identified as one of the most sensitive "tipping elements" of global climate change

\footnotetext{
${ }^{1}$ Department of Geography, University of Sheffield, Sheffield, UK.

${ }^{2}$ Earth System Sciences and Departement Geografie, Vrije Universiteit, Brussels, Belgium.

${ }^{3}$ Danish Meteorological Institute, Copenhagen, Denmark.

${ }^{4}$ Cooperative Institute for Research in Environmental Sciences, University of Colorado, Boulder, Colorado, USA.

${ }^{5}$ Sierra Nevada Research Institute, University of California, Merced, California, USA.

Copyright 2011 by the American Geophysical Union. 0148-0227/11/2011JD016387
}

[Lenton et al., 2008] and has undergone significant increases in its surface melt area and modeled runoff, as well as enhanced mass turnover, over the last 30-50 years [Hanna et al., 2008, 2009]. Its sensitivity and response to climate forcing are effectively measured through changes in its surface mass balance (SMB), which equals the main mass input through net snow accumulation minus the net seasonal runoff of surface meltwater. Nearly all previous published GrIS SMB studies are restricted to the period since about 1958, owing to availability of suitable gridded climate reanalysis

\footnotetext{
${ }^{6}$ Department of Geography, University of Utah, Salt Lake City, Utah, USA.

${ }^{7}$ Desert Research Institute, Reno, Nevada, USA.

${ }^{8}$ Department of Geophysics, University of Copenhagen, Copenhagen, Denmark.

${ }^{9}$ Institute for Marine and Atmospheric Research Utrecht, Utrecht University, Utrecht, Netherlands.

${ }^{10}$ Department of Geography, University of Calgary, Calgary, Alberta, Canada.

${ }^{11}$ Corporate Information and Computing Services, University of Sheffield, Sheffield, UK.
} 

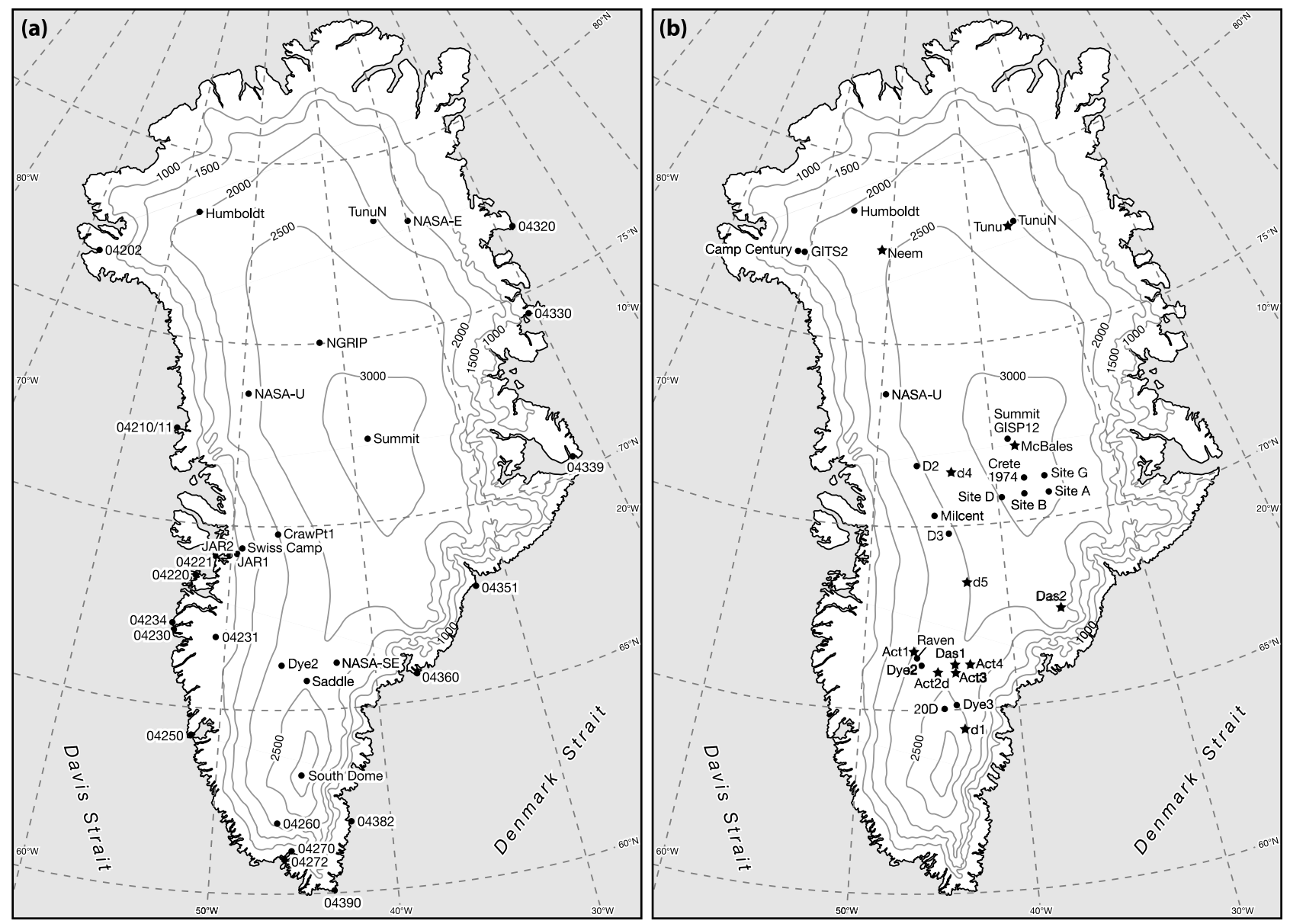

Figure 1. Maps of (a) Greenland weather stations and (b) Greenland shallow ice cores used in this study. Black dots (stars) in Figure 1b indicate Bales (McConnell) core sites.

data sets (typically European Centre for Medium-Range Weather Forecasts, ECMWF) that can be used as a basis for downscaling and for running spatially resolved SMB models [e.g., Hanna et al., 2005, 2008; Box et al., 2006; Fettweis, 2007; Mernild et al., 2010; Van den Broeke et al., 2009].

[3] However, this $\sim 50$ year period is still relatively short in climatological terms and does not include either the major warm period of the 1930s in Greenland [Box, 2002; Chylek et al., 2006] or any of the Little Ice Age period coming out of the Nineteenth Century. The one previous published study that has presented a longer SMB time series [Wake et al., 2009] was based on statistical relationships inferred between Greenland coastal weather station and ice core data and regional climate model (RCM) output-derived inland SMB for the last few decades of available model output. However, such relationships might break down with time and may not be as robust as a spatially resolved gridded climate data set covering the whole of Greenland for the study period. The latter has only recently (2010) become available in the form of the Twentieth Century Reanalysis (20CR) data set [Compo et al., 2006, 2011]. Therefore, here we build on the previous GrIS studies referenced above by presenting a novel GrIS SMB reconstruction for 1870-2010 based on downscaled and validated 20CR gridded climate data. Statistical comparison with a key existing published iceberg flux series enables us to make a preliminary evaluation of potential links between SMB and ice dynamics changes over the past century, and by so doing highlight an important area of further work. We also compare our new, extended GrIS SMB time series with key atmospheric circulation indices as well as Northern Hemisphere mean temperatures, in order to shed light on global and regional climate interactions with the GrIS, which may help to determine the ice sheet's sensitivity to ongoing climate change.

\section{Data and Methods}

\subsection{Greenland Climate and Glaciological Data}

[4] Monthly near-surface air-temperature (SAT) data for Greenland climate stations were mainly obtained for coastal Danish Meteorological Institute (DMI) stations [Cappelen, 2011] and for Greenland Climate Network (GC-Net) automatic weather stations of the Greenland Ice Sheet interior from Steffen and Box [2001] (locations in Figure 1a). However, coastal station 04202 Thule Airbase data from November 2006 were obtained by personal communication directly from the airbase. In addition, gridded SAT, precipitation and surface latent heat flux data from ECMWF operational and ERA-40 (re)analysis [Uppala et al., 2005] spanning 1958-2010 and 20CR reanalysis spanning 1870-2008 [Compo et al., 2006, 2011] were acquired for the Greenland region and bilinearly interpolated from 


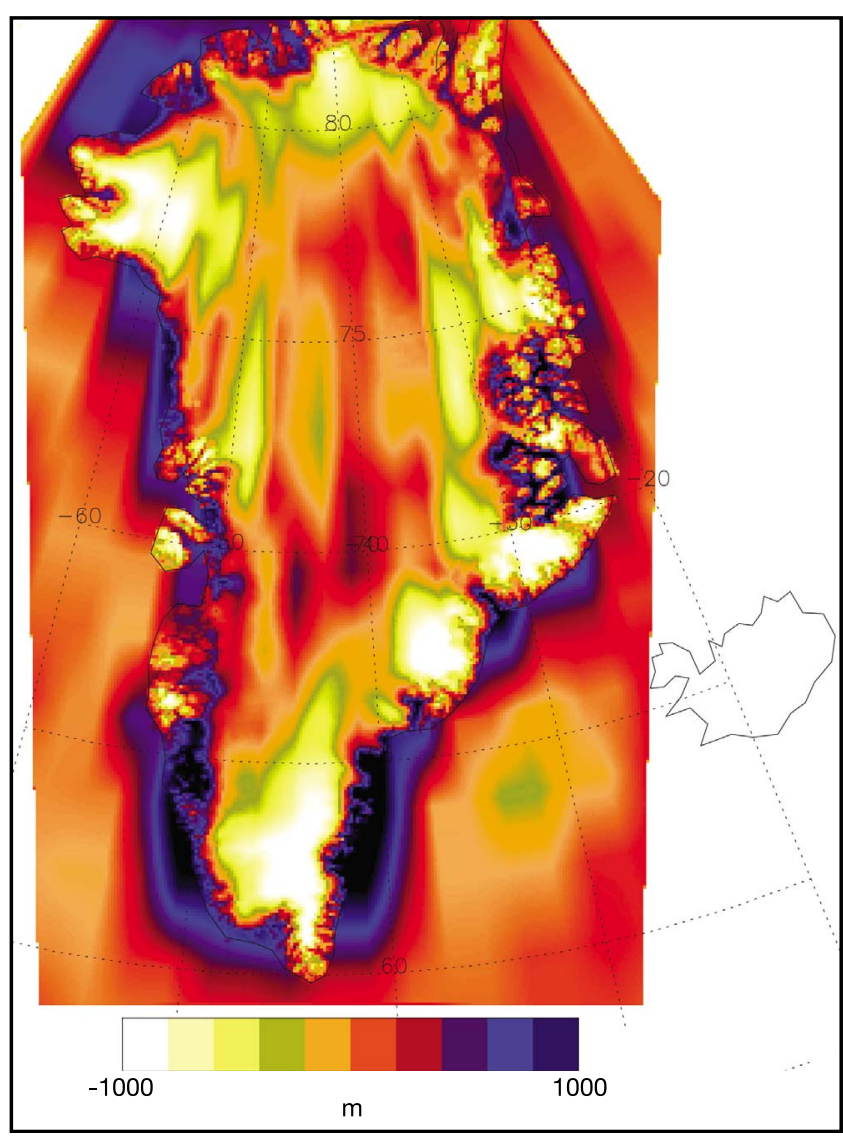

Figure 2. Twentieth Century Reanalysis (20CR) minus Huybrechts/Ekholm orography.

$2^{\circ} \times 2^{\circ}$ latitude/longitude (20CR reanalysis) and $1.125^{\circ} \times$ $1.125^{\circ}$ (ECMWF analyses) to a $5 \times 5 \mathrm{~km}$ polar stereographic grid. The in situ and gridded reanalysis SAT data sets were used, following Hanna et al. [2005, 2008], to derive ice sheet surface lapse rates on the basis of elevation differences of the bilinearly interpolated 20CR surface geopotential field (orography $=$ surface height) from a standard reference Greenland digital elevation model of established and relatively much greater accuracy [Ekholm, 1996] on the same $5 \times 5 \mathrm{~km}$ grid (Figure 2). For this purpose, we used lapse rates of $-8^{\circ} \mathrm{C} \mathrm{km}^{-1}$ for the GrIS interior $(>1000 \mathrm{~m}$ elevation) and $-6^{\circ} \mathrm{C} \mathrm{km}^{-1}$ for the marginal zones $(\leq 1000 \mathrm{~m})$; although we also experimented with more dynamic seasonally varying lapse rates (lower in summer for the lower elevation regions), the former blanket lapse-rate values gave the most accurate results of modeled compared with observed SAT summer values (Table 2). This step is important, as uncorrected SAT can be incorrect by several degrees Celsius over large regions of Greenland, and this correction typically brings downscaled reanalysis temperatures to within $0.5-1{ }^{\circ} \mathrm{C}$ of the in situ weather station values (see differences and mean absolute errors in Tables 1 and 2 and previous results reported by Hanna et al. [2005]).

[5] Ice core data (Figure $1 \mathrm{~b}$ and Tables 3 and 4; Hanna et al. [2006, Figure 1]) are used mainly for validating modeled snow accumulation for several dozen locations across the ice sheet. Sites from Vinther et al. [2010, Figure 1] are also used as a check on our long-term surface air temperature records (see section 2.2).

\subsection{Modeled Surface Mass Balance}

[6] Our SMB modeling approach is based on the widely used positive degree-day runoff/retention model of Janssens and Huybrechts [2000], which extends the pioneering work of Braithwaite and Olesen [1989] and Reeh [1991], and requires high-resolution (several kilometers), calibrated SAT, precipitation, and surface latent heat flux gridded data as inputs. The runoff/retention model first calculates expected positive degree days on the basis of monthly air temperature data, degree-day factors for ice and snow, and an assumed variability of subdaily (in our case 6-hourly) temperatures about the monthly mean temperature; the latter two parameters were previously tuned against Greenland field data [Janssens and Huybrechts, 2000]. In this study we used the annual version of the runoff model forced by monthly temperature and annual precipitation. Snow and rain fractions of total net annual precipitation are scaled from monthly SAT [Janssens and Huybrechts, 2000]. The runoff model incorporates a simple one-dimensional snowpack model. When the seasonal temperature reaches an adequate level, the surface melts and, in the snow-covered region, this meltwater is initially stored as capillary water within the snowpack. Eventually, the snowpack becomes saturated and runoff occurs, although melt needs to reach typically $60 \%$ of the annual precipitation before this can happen [Janssens and Huybrechts, 2000]. Any rain is assumed to run off. The runoff/retention scheme also accounts for superimposed ice formation and subsequent melt and implicitly takes into account the ice-albedo negative feedback (more winter snowfall through its high surface albedo and lower degreeday factor, and the higher meltwater retention capacity of the snowpack, delays subsequent summer runoff, for example, see discussions by Hanna et al. [2008] and Murray, 2010) although absorbed solar radiation, which is the most prominent source for melt energy [e.g., Van den Broeke et al., 2008], is not explicitly calculated. This Greenland runoff/ SMB model has been used in many previous studies [e.g., Fettweis et al., 2008; Hanna et al., 2002, 2005, 2008, 2009; Hodson et al., 2011; Krabill, 2004; Murray, 2010; Rignot et al., 2008; Sundal et al., 2009, 2011], and, being a degree-day model, has the advantage of inherent simplicity over a more sophisticated, but demanding in terms of input data, energy balance modeling (EBM) approach. This makes our Greenland runoff/SMB model valuable for long-term climatological studies of the ice sheet for which limited data are available to drive the model prior to the satellite era. Importantly in this context, radiation and turbulent heat fluxes, which are quite poorly constrained over the GrIS, especially prior to the 1970 s, are not required to drive the runoff/SMB model.

[7] The new 1870-2010 GrIS SMB annual time series was constructed from a combination of 20CR (1870-1957) [Compo et al., 2006, 2011], ECMWF ERA-meteorological reanalysis [Uppala, 2005] data from 1958 to 2001, and ECMWF operational analysis from 2002 to 2010. The year 1870 is spin-up in the 20CR [Compo, 2011, Table 3], so it is ignored in the formal SMB trend analysis reported below. Near-surface $(2 \mathrm{~m})$ air temperatures, precipitation and surface latent heat flux from the 20CR and ECMWF (re)analyses 
Table 1. Height Differences (Hdiff) and Near-Surface Air Temperature Differences (Tdiff) Between Raw Twentieth Century Reanalysis and Surface Stations ${ }^{\mathrm{a}}$

\begin{tabular}{|c|c|c|c|}
\hline Station & $\begin{array}{l}\text { Hdiff } \\
(\mathrm{m})\end{array}$ & $\begin{array}{c}\text { Tdiff_year } \\
\left({ }^{\circ} \mathrm{C}\right)\end{array}$ & $\begin{array}{c}\text { Tdiff_summer } \\
\left({ }^{\circ} \mathrm{C}\right)\end{array}$ \\
\hline \multicolumn{4}{|c|}{$D M I$} \\
\hline 04202/Pituffik & 150 & 4.8 & -1.5 \\
\hline 04210/04211/Upernavik & 721 & -1.2 & -3.3 \\
\hline 04220/Aasiaat & 383 & 1.5 & 0.2 \\
\hline 04221/Ilulissat & 482 & -1.7 & -4.2 \\
\hline 04230/04234/Sisimiut & 178 & 1.5 & 1.3 \\
\hline 04231/Kangerlussuaq & 606 & -2.4 & -5.8 \\
\hline 04250/Nuuk & 850 & -5.1 & -2.6 \\
\hline 04260/Paamiut & 895 & -3.4 & -1.7 \\
\hline 04270/Narsarsuaq & 725 & -5.1 & -7.9 \\
\hline 04272/Qaqortoq & 612 & -2.9 & -3.9 \\
\hline 04320/Danmarkshavn & 335 & 3.9 & -2.3 \\
\hline 04330/Daneborg & 401 & 2.5 & -2.1 \\
\hline 04339/Ittoqqortoormiit & 136 & 3.1 & -0.6 \\
\hline 04351/Aputiteeq & 903 & -2.0 & -2.6 \\
\hline 04360/Tasiilaq & 515 & -4.6 & -6.0 \\
\hline 04382/Ikermiuarsuk & 990 & -2.7 & -2.7 \\
\hline 04390/Ikerasassuaq & 231 & -0.9 & -0.7 \\
\hline Mean & 536 & -0.9 & -2.7 \\
\hline \multicolumn{4}{|c|}{$G C-N e t$} \\
\hline Swiss Camp & 89 & 2.1 & -0.1 \\
\hline Crawford Point 1 & -226 & 3.3 & 2.0 \\
\hline NASA-U & -524 & 4.4 & 3.2 \\
\hline Humboldt & -599 & 7.9 & 5.2 \\
\hline Summit & -102 & 2.8 & 2.0 \\
\hline Tunu-N & 53 & 5.4 & 3.4 \\
\hline Dye-2 & -119 & 1.9 & 1.6 \\
\hline JAR 1 & 80 & 2.6 & 3.0 \\
\hline Saddle & -374 & 0.9 & -0.5 \\
\hline South Dome & -1197 & 8.5 & 6.7 \\
\hline NASA-E & -556 & 3.4 & 6.8 \\
\hline NGRIP & -188 & 3.5 & 3.1 \\
\hline NASA-SE & -405 & 3.4 & 3.0 \\
\hline JAR 2 & 298 & -0.4 & -1.2 \\
\hline Mean & -269 & 3.6 & 2.7 \\
\hline
\end{tabular}

${ }^{\mathrm{a}}$ Tdiff is given for the year and summer (June, July, August) seasons. Positive bias means $20 \mathrm{CR}$ has a relatively higher value.

were bilinearly interpolated to a $5 \times 5 \mathrm{~km}$ polar stereographic grid [Janssens and Huybrechts, 2000; Ekholm, 1996]. Small $\left(\sim 0.5^{\circ}-1^{\circ} \mathrm{C}\right)$ residual mean monthly temperature differences between 20CR and ECMWF analysis data were corrected when splicing the two series together (Figure 3). The resulting GrIS-averaged temperature time series for midsummer (July) suggests a recent 2000s peak slightly in excess of that of the 1930s Greenland warm period [Chylek et al., 2006; Box et al., 2009] but with considerable decadal variability that may partly be related to the North Atlantic Oscillation (NAO) [Hanna and Cappelen, 2003] as well as other climatic forcing factors. Surface latent heat flux was used as a basis for calculating evaporation and sublimation: essential for deriving net precipitation and accumulation [Hanna et al., 2005]. The Janssens and Huybrechts [2000] runoff model was used to determine the snow fraction of net precipitation, that is, snow accumulation, on the basis of input SAT. Following section 2.1, empirically derived ice sheet surface lapse rates were used to correct 20CR and ECMWF modeled near-surface air temperatures, supported by additional analogous data analysis here (Figures 4 and 5 and Tables 1 and 2), and resulting modeled mean summer temperatures were generally within $0.5^{\circ}-1^{\circ} \mathrm{C}$ of observed Danish Meteorological Institute (DMI) and Greenland Climate Network (GC-Net) station values (Table 2). Also, modeled annual temperatures generally correlate significantly $(\mathrm{r} \sim 0.3-0.4)$ with $\delta^{18} \mathrm{O}$ isotope records for thirteen long-running (typically 1870-1970s) sites across the GrIS; sites are taken from Vinther et al. [2010, Table 1, Figure 1]. This supports our long-term surface air temperature reconstructions, although comparing instrumental $2 \mathrm{~m}$ air temperature with a proxy measure of surface temperature is not really a direct comparison.

[8] Precipitation output from both 20CR and ECMWF were calibrated against the Bales et al. [2009] kriged "corrected precipitation" map based on the latest and most comprehensive compilation of ice core snow accumulation and DMI coastal precipitation data, the latter corrected for windcatch loss [Bales et al., 2009], to remove spatial biases in the (re)analysis precipitation fields. These biases are typically too low in the central and northern interior and too high nearer the southern coasts for ECMWF precipitation [Hanna

Table 2. Differences and Mean Absolute Errors Between Corrected 20CR-Based and in Situ Near-Surface Air Temperatures, Based on All Available Monthly Mean Summer (June, July, and August) Data for $1948-2008^{\mathrm{a}}$

\begin{tabular}{|c|c|}
\hline Station & $\begin{array}{c}\text { Near-Surface Air } \\
\text { Temperature Difference } \\
\left({ }^{\circ} \mathrm{C}\right)\end{array}$ \\
\hline \multicolumn{2}{|c|}{$D M I$} \\
\hline 04202/Pituffik & -0.6 \\
\hline 04210/04211/Upernavik & 1.1 \\
\hline 04220/Aasiaat & 2.5 \\
\hline 04221/Ilulissat & -1.3 \\
\hline 04230/04234/Sisimiut & 2.5 \\
\hline 04231/Kangerlussuaq & -2.2 \\
\hline 04250/Nuuk & 2.5 \\
\hline 04260/Paamiut & 3.7 \\
\hline 04270/Narsarsuaq & -3.6 \\
\hline 04272/Qaqortoq & -0.2 \\
\hline 04320/Danmarkshavn & -0.3 \\
\hline 04330/Daneborg & 0.3 \\
\hline 04339/Ittoqqortoormiit & 0.3 \\
\hline 04351/Aputiteeq & 2.8 \\
\hline 04360/Tasiilaq & -2.9 \\
\hline 04382/Ikermiuarsuk & 3.3 \\
\hline 04390/Ikerasassuaq & 0.7 \\
\hline MAE based on DMI mean difference & 0.5 \\
\hline \multicolumn{2}{|c|}{ GC-Net } \\
\hline Swiss Camp & 0.7 \\
\hline Crawford Point 1 & 0.2 \\
\hline NASA-U & -1.0 \\
\hline Humboldt & 0.4 \\
\hline Summit & 1.2 \\
\hline Tunu-N & 3.9 \\
\hline Dye-2 & 0.7 \\
\hline JAR 1 & 0.0 \\
\hline Saddle & 0.2 \\
\hline South Dome & -2.9 \\
\hline NASA-E & 2.4 \\
\hline NGRIP & 1.6 \\
\hline NASA-SE & -0.2 \\
\hline JAR 2 & 0.6 \\
\hline MAE based on GC-Net mean difference & 0.5 \\
\hline
\end{tabular}

${ }^{a}$ Positive bias means $20 \mathrm{CR}$ has higher value. MAE, mean absolute error. 
Table 3. Correlation Coefficients Between ECMWF and 20CR-Reanalysis-Based Modeled and Observed Snow Accumulations, Based on Shallow Ice Cores Reported by Hanna et al. [2006]

\begin{tabular}{|c|c|c|c|c|c|c|}
\hline Core Site & $\begin{array}{l}\text { Latitude } \\
\text { (deg) }\end{array}$ & $\begin{array}{l}\text { Longitude } \\
\text { (deg) }\end{array}$ & Period & $\begin{array}{l}\text { Elevation } \\
\text { (m) }\end{array}$ & $\begin{array}{c}r \\
\text { (core, ECMWF) }\end{array}$ & $\begin{array}{c}r \\
\text { (core, 20CR) }\end{array}$ \\
\hline NASA-U & 73.8 & -49.5 & 1958-1994 & 2327 & 0.54 & 0.54 \\
\hline GITS & 77.1 & -61.0 & 1958-1995 & 1877 & 0.13 & 0.22 \\
\hline Humboldt & 78.5 & -56.8 & 1958-1994 & 1961 & 0.39 & 0.17 \\
\hline Crawford Point & 69.8 & -47.1 & 1982-1994 & 1913 & 0.53 & 0.51 \\
\hline STunu A & 69.8 & -35.0 & 1976-1996 & 2871 & 0.79 & 0.77 \\
\hline Saddle A & 66.0 & -44.5 & 1976-1996 & 2451 & 0.75 & 0.76 \\
\hline SDome A & 63.2 & -44.8 & 1978-1996 & 2862 & 0.70 & 0.47 \\
\hline NASA-EA & 75.0 & -30.0 & 1964-1996 & 2601 & 0.49 & 0.38 \\
\hline 7147 & 71.1 & -47.2 & 1974-1996 & 2182 & 0.70 & 0.55 \\
\hline 7247 & 71.9 & -47.5 & 1974-1996 & 2363 & 0.64 & 0.36 \\
\hline 7551 & 75.0 & -51.0 & 1965-1996 & 2224 & 0.44 & 0.66 \\
\hline 7653 & 76.0 & -53.0 & 1977-1996 & 2158 & 0.49 & 0.50 \\
\hline Dye-2b & 66.0 & -46.0 & 1958-1997 & 2238 & -0.09 & -0.07 \\
\hline 6345 & 63.8 & -45.0 & 1977-1997 & 2729 & 0.57 & 0.46 \\
\hline 6943 & 69.2 & -43.0 & 1977-1997 & 2492 & 0.77 & 0.66 \\
\hline 6945 & 69.0 & -45.0 & 1977-1997 & 2147 & 0.82 & 0.83 \\
\hline 7345 & 73.0 & -45.0 & 1975-1997 & 2810 & 0.73 & 0.53 \\
\hline SDo2 & 63.1 & -46.4 & 1980-1998 & 2662 & 0.83 & 0.55 \\
\hline cnp1 & 73.2 & -32.1 & 1958-1998 & 2951 & 0.26 & 0.21 \\
\hline cnp2 & 71.9 & -32.4 & 1960-1998 & 2749 & -0.02 & -0.04 \\
\hline cnp3 & 70.5 & -33.5 & 1964-1998 & 2923 & 0.60 & 0.40 \\
\hline jav2 & 72.6 & -47.1 & 1968-1998 & 2608 & 0.63 & 0.35 \\
\hline jav3 & 70.5 & -46.1 & 1981-1998 & 2256 & 0.75 & 0.56 \\
\hline kul1 & 67.5 & -39.0 & 1975-1998 & 2409 & 0.59 & 0.58 \\
\hline uak1 & 65.5 & -44.5 & 1958-1998 & 2516 & 0.53 & 0.41 \\
\hline uak4 & 65.5 & -46.1 & 1977-1998 & 2344 & 0.51 & 0.42 \\
\hline uak5 & 65.4 & -46.5 & 1978-1998 & 2266 & 0.33 & 0.32 \\
\hline Dye-3 & 65.2 & -43.9 & 1976-1998 & 2481 & 0.46 & 0.46 \\
\hline d1 & 64.5 & -43.5 & 1958-1998 & 2580 & 0.34 & 0.15 \\
\hline $\mathrm{d} 2$ & 71.8 & -46.2 & 1958-1998 & 2534 & 0.67 & 0.53 \\
\hline $\mathrm{d} 3$ & 68.9 & -44 & 1958-1998 & 2433 & 0.74 & 0.66 \\
\hline sandya & 72.5 & -38.3 & 1958-2002 & 3209 & 0.55 & 0.55 \\
\hline Das1 & 66 & -44 & 1958-2002 & 2499 & 0.66 & 0.55 \\
\hline Das2 & 67.5 & -36.1 & 1958-2002 & 2967 & 0.78 & 0.63 \\
\hline Basin 1 & 71.8 & -42.4 & 1976-2002 & 2916 & 0.57 & 0.45 \\
\hline Basin 2 & 68.3 & -44.8 & 1980-2002 & 2171 & 0.51 & 0.47 \\
\hline Basin 4 & 62.3 & -46.3 & 1969-2002 & 2300 & 0.13 & 0.07 \\
\hline Basin 5 & 63.9 & -46.4 & 1964-2002 & 2472 & 0.26 & 0.18 \\
\hline Basin6 & 67 & -41.7 & 1983-2002 & 2416 & 0.52 & 0.50 \\
\hline Basin 7 & 67.5 & -40.4 & 1983-2002 & 2443 & 0.55 & 0.63 \\
\hline Basin 8 & 69.8 & -36.4 & 1958-2002 & 2970 & 0.62 & 0.46 \\
\hline Basin 9 & 65 & -44.9 & 1958-2002 & 2599 & 0.28 & 0.21 \\
\hline d5 & 68.5 & -42.9 & 1970-2002 & 2469 & 0.69 & 0.58 \\
\hline
\end{tabular}

${ }^{\mathrm{a}}$ Correlations significant at the $1 \%(5 \%)$ level are in bold (italics).

et al., 2006], and arise from the low-resolution meteorological analysis orography being too smooth and high around the outer edges of Greenland (Figure 2), blocking the passage of precipitation far inland and causing too much precipitation to orographically fall out around the coasts. The Bales et al. [2009] precipitation data are generally representative of the period 1950-2000, so, for each $5 \times 5 \mathrm{~km}$ grid point, we first divided the Bales et al. [2009] precipitation by the 20CR and ECMWF mean annual precipitations for the same period (with all data sets bilinearly interpolated to the same $5 \times$ $5 \mathrm{~km}$ Greenland grid) and then used the resulting regionally variable scaling factor to calibrate individual years' modeled precipitation. This is the basis of our SMB1 time series described below.

[9] In addition we carried out a separate similar calibration of our modeled (net solid) ECMWF precipitation against the Burgess et al. [2010] Greenland accumulation map, which represents the 1958-2007 period, as the basis of our SMB2 time series that is also described in section 3. The Burgess et al. [2010] accumulation is based on Polar MM5 regional climate model solid precipitation output calibrated against firn core and meteorological station data. We assessed (see section 3) the degree of difference between the two calibrations. Modeled snow accumulation time series from both 20CR (1870-2008) and ECMWF (1958-2008) showed statistically significant agreement with long-term annual snow accumulation series from ice cores [Hanna et al., 2006; Glueck, M. F., R. C. Bales, and J. R. McConnell, Regional patterns in multicentury records of annual accumulation on the Greenland Ice Sheet, unpublished manuscript] (Figure 6 and Tables 3 and 4).

[10] The 20CR evaporation was unrealistically large (as determined through comparison with ECMWF evaporation and 20CR and ECMWF precipitation), although the 20CR 
Table 4. Correlation Coefficients Between 20CR-Reanalysis-Based Modeled and Observed Snow Accumulations, Based on Mainly Long-Term, Centennial Timescale Shallow Ice Cores Not Reported by Hanna et al. [2006]

\begin{tabular}{|c|c|c|c|c|c|c|}
\hline Core Site & Source & $\begin{array}{l}\text { Latitude } \\
\text { (deg) }\end{array}$ & $\begin{array}{l}\text { Longitude } \\
\text { (deg) }\end{array}$ & $\begin{array}{l}\text { Elevation } \\
(\mathrm{m})\end{array}$ & Period & $\begin{array}{c}r \\
(\text { core }, 20 \mathrm{CR})\end{array}$ \\
\hline Camp Century & Danish & 77.18 & -61.11 & 1914 & $1870-1974$ & 0.22 \\
\hline GITS2 & PARCA & 77.18 & -61.1 & 1910 & 1870-1995 & 0.16 \\
\hline Humboldt & Danish & 78.52 & -56.82 & 1995 & 1870-1994 & 0.06 \\
\hline Site A & Danish & 70.63 & -35.82 & 3092 & 1870-1984 & 0.37 \\
\hline Site B & Danish & 70.65 & -37.48 & 3139 & 1870-1979 & 0.50 \\
\hline Site D & Danish & 70.64 & -39.62 & 3018 & 1870-1983 & 0.46 \\
\hline Site G & Danish & 71.15 & -35.84 & 3098 & $1870-1983$ & 0.43 \\
\hline Crete1974 & Danish & 71.12 & -37.32 & 3172 & $1870-1973$ & 0.41 \\
\hline Milcent & Danish & 70.30 & -45.0 & 2410 & 1870-1966 & 0.43 \\
\hline NASA-U & PARCA & 73.83 & -49.48 & 2368 & 1870-1994 & 0.26 \\
\hline D2 & PARCA & 71.75 & -46.16 & 2640 & 1870-1998 & 0.41 \\
\hline D3 & PARCA & 69.8 & -44 & 2560 & 1870-1998 & 0.54 \\
\hline Raven & PARCA & 66.48 & -46.28 & 2053 & 1870-1997 & 0.07 \\
\hline Dye2 & Danish & 66.29 & -46.20 & 2100 & 1870-1973 & 0.10 \\
\hline GISP12 & GISP project & 72.6 & -38.5 & 3200 & 1870-1987 & 0.14 \\
\hline Summit99 & PARCA & 72.6 & -38.5 & 3210 & 1870-1998 & 0.22 \\
\hline $20 \mathrm{D}$ & Whung et al. [1994] & 65.01 & -44.95 & 2625 & 1870-1984 & 0.26 \\
\hline Dye-3 & Danish & 65.18 & -43.8 & 2480 & $1870-1983$ & 0.43 \\
\hline Tunu & PARCA/ McConnell & 78 & -34 & 2110 & 1870-1994 & 0.12 \\
\hline $\mathrm{d} 4$ & McConnell & 71.4 & -44.0 & 2766 & 1870-2002 & 0.41 \\
\hline d5 & McConnell & 68.5 & -42.9 & 2519 & 1870-2002 & 0.33 \\
\hline McBales & McConnell & 72.5 & -38.3 & 3258 & 1870-2002 & 0.12 \\
\hline Act $2 d$ & McConnell & 66 & -45.2 & 2408 & 1870-2003 & 0.15 \\
\hline Act 3 & McConnell & 66 & -43.6 & 2508 & $1870-2003$ & 0.45 \\
\hline d1 & PARCA & 64.5 & -43.5 & 2580 & 1886-1998 & 0.28 \\
\hline Das1 & Das/McConnell & 66 & -44 & 2549 & 1908-2002 & 0.39 \\
\hline Das2 & Das/McConnell & 67.5 & -36.1 & 3036 & 1936-2002 & 0.57 \\
\hline act1 & McConnell & 66.5 & -46.3 & 2145 & 1958-2003 & 0.43 \\
\hline act4 & McConnell & 66 & -42.8 & 2353 & 1979-2003 & 0.46 \\
\hline
\end{tabular}

${ }^{a}$ Correlations significant at the $1 \%(5 \%)$ level are in bold (italics). PARCA, Program for Arctic Regional Climate Assessment.

and ECMWF evaporation series correlate well (not shown), so a rescaling factor of 0.3 was applied to all years' 20CR evaporation to bring $20 \mathrm{CR}$ mean evaporation into line with ECMWF mean evaporation. 20CR precipitation and runoff variances, suppressed by the inherently lower spatial resolution of the $20 \mathrm{CR}\left(2 \times 2^{\circ}\right)$ compared with ECMWF (re)analysis $\left(1.125 \times 1.125^{\circ}\right)$, were also rescaled to match that of ECMWF for the 1958-2008 overlap period, to produce a statistically coherent and self-consistent SMB time series.

[11] We assume that the ECMWF analysis is superior to 20CR for the common period because of the relative lack of in situ data, mainly restricted to coastal stations around Greenland, assimilated into both (re)analyses, and the inclusion of some satellite/upper air data in the ECMWF, whereas the 20CR uses solely synoptic surface and sea level pressure observations and monthly mean sea-surface-temperature/ sea-ice boundary conditions from HadISST1 [Compo et al., 2006, 2011]. By the very nature of their formulation, longterm reanalysis products such as 20CR are likely to be less accurate and more uncertain, especially in the earlier parts of their time series, than data-richer reanalyses covering, for example, the satellite era. Comparison of reanalysis-based modeled snowfall with net snow accumulation gleaned from shallow ice cores shows generally higher correlations for ECMWF (mean $r=0.53$ ) than 20CR (mean $r=0.44$ ) for the common overlap (1958-2008) period. Correlations for individual core sites are shown in Table 3; however, core-20CR accumulation correlations are still generally significant for the full (1870-2008) 20CR time period (Table 4). Hence we use ECMWF as the default analysis for 1958-2010, and also because the 20CR is currently lacking 2009 and 2010 data. Nevertheless, the 20CR shows significant skill in replicating whole-Greenland climate for the pre-1958 period, supported by the good agreement between 20CR and ECMWF precipitation, runoff and SMB for the overlap period (Figure 7).

[12] Our approach represents a significant advance on the 1866-2005 GrIS SMB time series of Wake et al. [2009], who necessarily used only spatiotemporal correlation information from coastal weather stations and ice cores, rather than much more spatially extensive and coherent reanalysis climate data, as a basis for modeling SMB across the ice sheet for the pre-1958 period. While their study was pioneering, we take advantage of the newly available and novel 20CR to refine and build on their earlier results, and to provide a gridded GrIS SMB data set that is more in keeping with existing products covering the last 50 years [e.g., Hanna et al., 2008; Box et al., 2006; Van den Broeke et al., 2009]. Unlike Wake et al. [2009], we use a single and therefore self-consistent climate data type and downscaling scheme (based on meteorological reanalysis data and the work of Janssens and Huybrechts [2000]) for the entire period of study. Wake et al. [2009] spliced together two different climate (SAT and precipitation or snow accumulation) series from J. Box (1866-1957) and E. Hanna (1958-2005) to produce their GrIS SMB anomaly time series. They used climate anomalies rather than actual values to force their SMB model, with the aim of reducing sensitivity of the SMB output to possible 


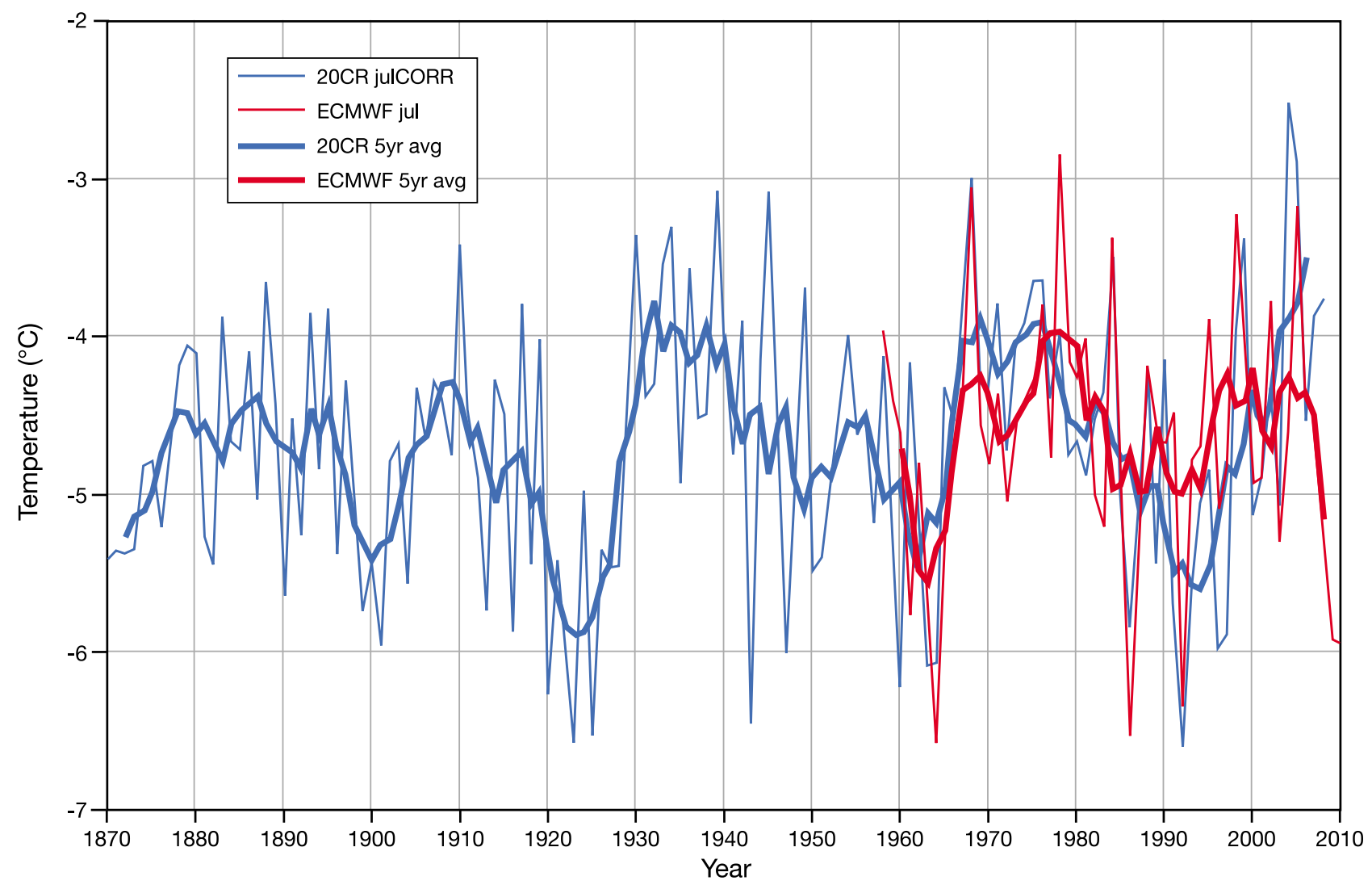

Figure 3. The 20CR and ECMWF July 2-m air temperature series and their 5 year running means averaged across the Greenland Ice Sheet, calibrated on the basis of near-surface ice sheet lapse rates derived from weather station data; the 20CR series has been spliced to fit the ECMWF temperature series mean July value for the common overlap (1958-2008) period.

biases in actual precipitation and temperature values. However, this approach necessitated assuming parameterized temperature and precipitation base fields from previous work [Janssens and Huybrechts, 2000], and their precipitation field is biased low compared with updated estimates of Greenland precipitation [e.g., Burgess et al., 2010; Ettema et al., 2009]. It should also be pointed out that Wake et al. [2009] used snow accumulation anomalies to scale their baseline precipitation field for the first part (1866-1957) of the series, although since most incoming precipitation is snow, this is a reasonable approximation in most areas, with greatest differences likely in the warmer parts of the ice sheet.

[13] Uncertainties of modeled whole ice sheet SMB in the present study are estimated to be $\pm 20 \%$ for accumulation and $\pm 25 \%$ for runoff. These uncertainty values are based (1) on regional calibration against real accumulation data but with most remaining uncertainties in Southeast Greenland [e.g., Bales et al., 2009; Burgess et al., 2010] and (2) on typical $\sim 0.5^{\circ}-1{ }^{\circ} \mathrm{C}$ errors of our downscaled near-surface air temperatures given that meltwater ablation typically changes by $\sim \pm 30 \%$ for every $1{ }^{\circ} \mathrm{C}$ change in surface air temperature [e.g., Van de Wal and Oerlemans, 1994]. There are also uncertainties in the parameters, specifically the degree-day factors for ice and snow and fixed standard deviations of all temperatures during a month, used in our runoff model, although these parameters are taken as standard and are based on previous Greenland fieldwork results referenced by Janssens and Huybrechts [2000]. Although we use most of the main existing temperature and accumulation data sets for the ice sheet, more spatially and temporally extensive validation data, especially precipitation and accumulation data from southeast Greenland, will help to narrow these uncertainty ranges.

[14] We provide comparison of our modeled SMB against an independent, previously published SMB time series derived from the RACMO2.1/GR regional climate model (RCM) for the 1958-2008 common overlap period [van den Broeke et al., 2009]. RACMO2.1/GR is adapted from the second version of the regional atmospheric climate model RACMO2. The atmospheric dynamic description is taken from the High-Resolution Limited Area Model (HIRLAM), while the parameterizations of the physical processes are equal to the ECMWF numerical weather prediction model. The ERA-40 fields (1957-2002) and after that the operational analyses (2002-2008) from ECMWF were used to initialize the meteorological fields at the start of the iteration and force the model at lateral boundaries. The interior of the domain is allowed to evolve freely, and only ice-free sea surface temperatures and sea ice fraction are prescribed. The model was coupled to a physical snow model that treats surface albedo as function of snow/firn/ice properties, meltwater percolation, retention and refreezing and applied over 


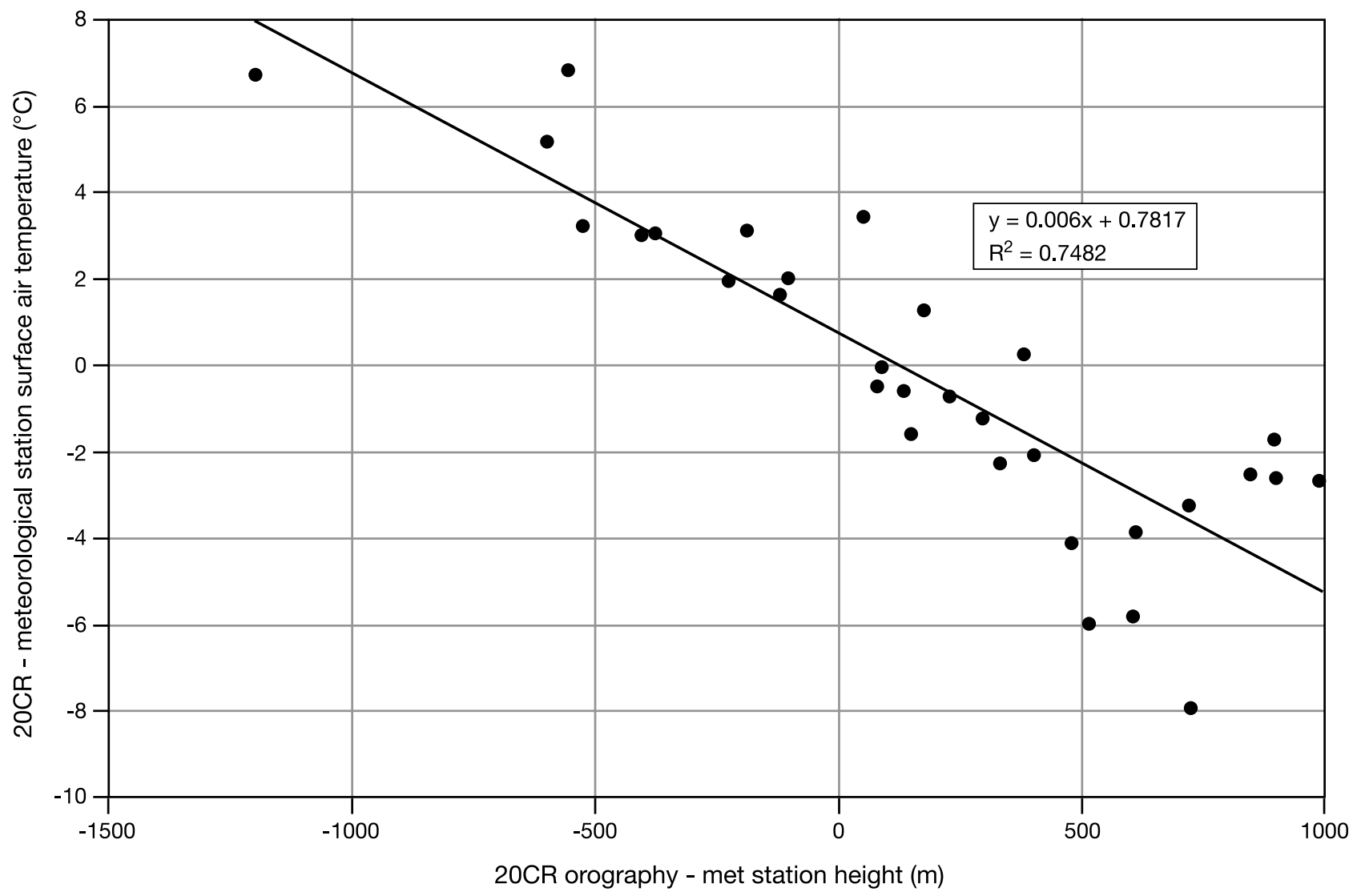

Figure 4. The 20CR minus Danish Meteorological Institute (DMI) and Greenland Climate Network (GCNet) meteorological station mean summer (June, July, and August) near-surface air temperature differences versus $20 \mathrm{CR}$ minus meteorological station surface height differences, based on all available data from 1948 to 2008. The slope of the linear least squares regression line yields an ice sheet near-surface temperature lapse rate of $-6^{\circ} \mathrm{C} \mathrm{km}^{-1}$.

a domain that includes the GrIS and its surrounding oceans and islands at high horizontal resolution $(\sim 11 \mathrm{~km})$. A more detailed description and evaluation of RACMO2/GR and the snow model are given by Ettema et al. [2009, 2010a, 2010b].

\section{Results}

\subsection{SMB and Component Mean Values}

[15] Our newly constructed Greenland Hybrid SMB1 1870-2010 annual series tuned against the Bales et al. [2009] Greenland accumulation map is shown in Figure 8, together with the component precipitation and runoff series, and our SMB2 series tuned against the Burgess et al. [2010] accumulation map (see section 2.2, paragraphs 3 and 4, for details of this tuning) is shown for comparison in Figure 9. There are very significant differences in absolute values of modeled SMB between our SMB1 and SMB2 time series (Figure 9 and Tables 5 and 6). This amounts to some $254 \mathrm{~km}^{3} \mathrm{yr}^{-1}$ for the whole 1871-2010 period and is largely due to the $218 \mathrm{~km}^{3} \mathrm{yr}^{-1}$ difference in mean annual precipitation between the two sets of data (Table 6). This difference in absolute SMB is equivalent to current observed rates of mass loss from GRACE [Rignot et al., 2011]. The significance of these differences in SMB can be illustrated when one considers that this $\sim 0.7 \mathrm{~mm} \mathrm{yr}^{-1}$ SLE SMB difference is equivalent to 38 and $22 \%$ of the observed global sea level trends ( 1.8 and $3.1 \mathrm{~mm} \mathrm{yr}^{-1}$ ) for the periods 1961-2003 and 1993-2003, respectively [Intergovernmental Panel on Climate Change, 2007]. The $37 \mathrm{~km}^{3} \mathrm{yr}^{-1}$ difference in runoff is due to greater modeled precipitation in SMB2 slightly delaying seasonal runoff initiation across the ice sheet compared with SMB1, since both our SMB reconstructions use the same downscaled SAT.

\subsection{Description of Variability and Trends in 1870-2010 SMB}

[16] Summary statistics of SMB and component means, standard deviations and linear least squares regression trends for the whole and sub(climatological normal) periods are given in Tables 3 and 4 . Note the significant decreasing (increasing) trend in precipitation and SMB (runoff) for the whole period. Significant trends were not noted by Wake et al. [2009], although they also show a noticeable decline in SMB for the whole time period (Figure 9). Modeled SMB reaches a high peak during the early 1920 s owing to record low modeled runoff and relatively high modeled precipitation at this time (Figure 8). Modeled precipitation peaks slightly higher later during the 1920s, when runoff was rapidly increasing to reach an early twentieth-century peak during the Greenland warm spell of the 1930s [Box, 2002]. SMB was therefore rapidly decreasing between the mid1920s and mid-1930s. Thereafter, precipitation declined until 

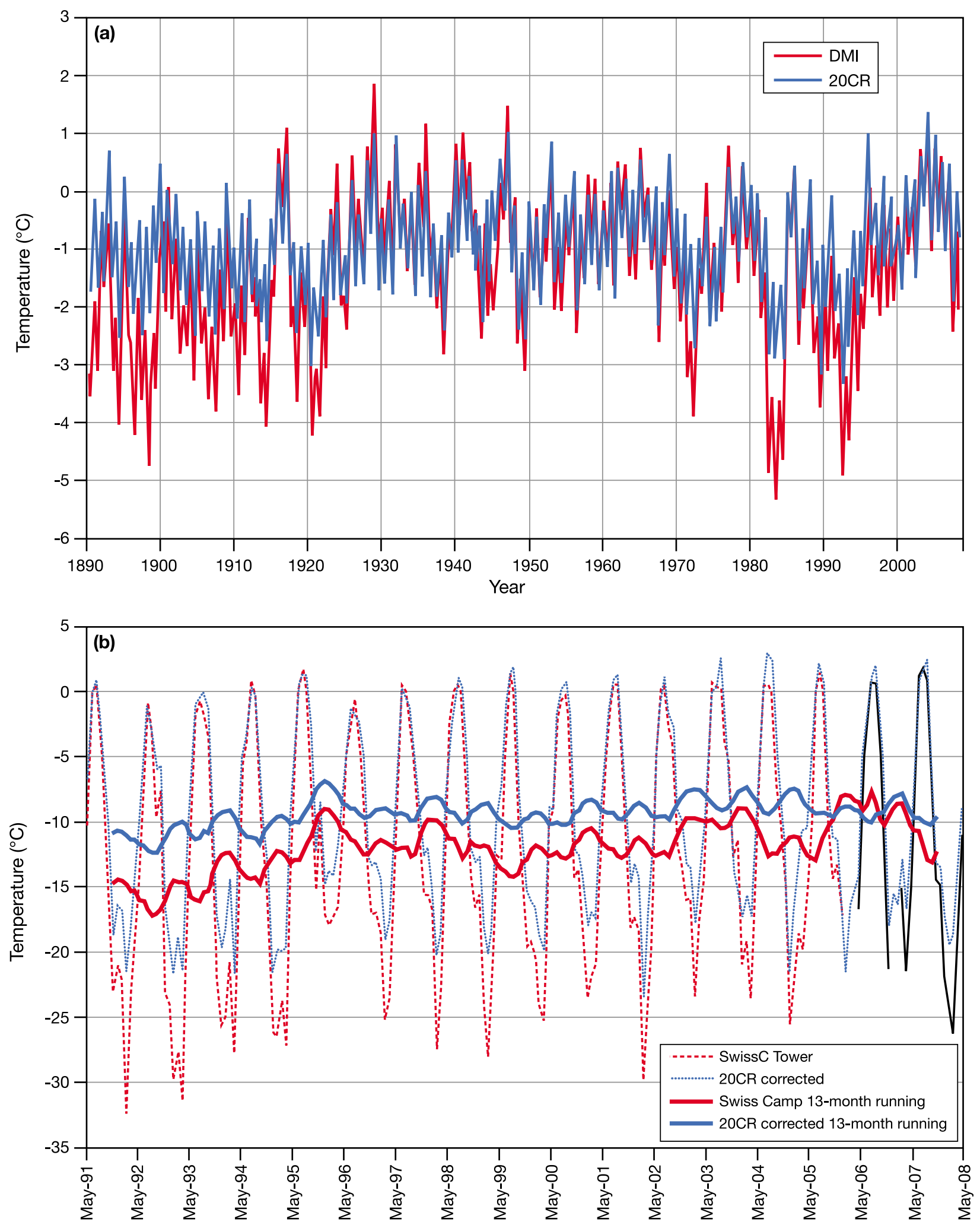

Figure 5. (a) Modeled (based on 20CR) and observed (DMI) monthly $2 \mathrm{~m}$ temperature at station 04250 Nuuk, smoothed using 13 month running means to emphasize interannual-decadal and longer variations. (b) Modeled (20CR) and observed (DMI) monthly $2 \mathrm{~m}$ temperature at Swiss Camp. See Figure 1a for station locations. 

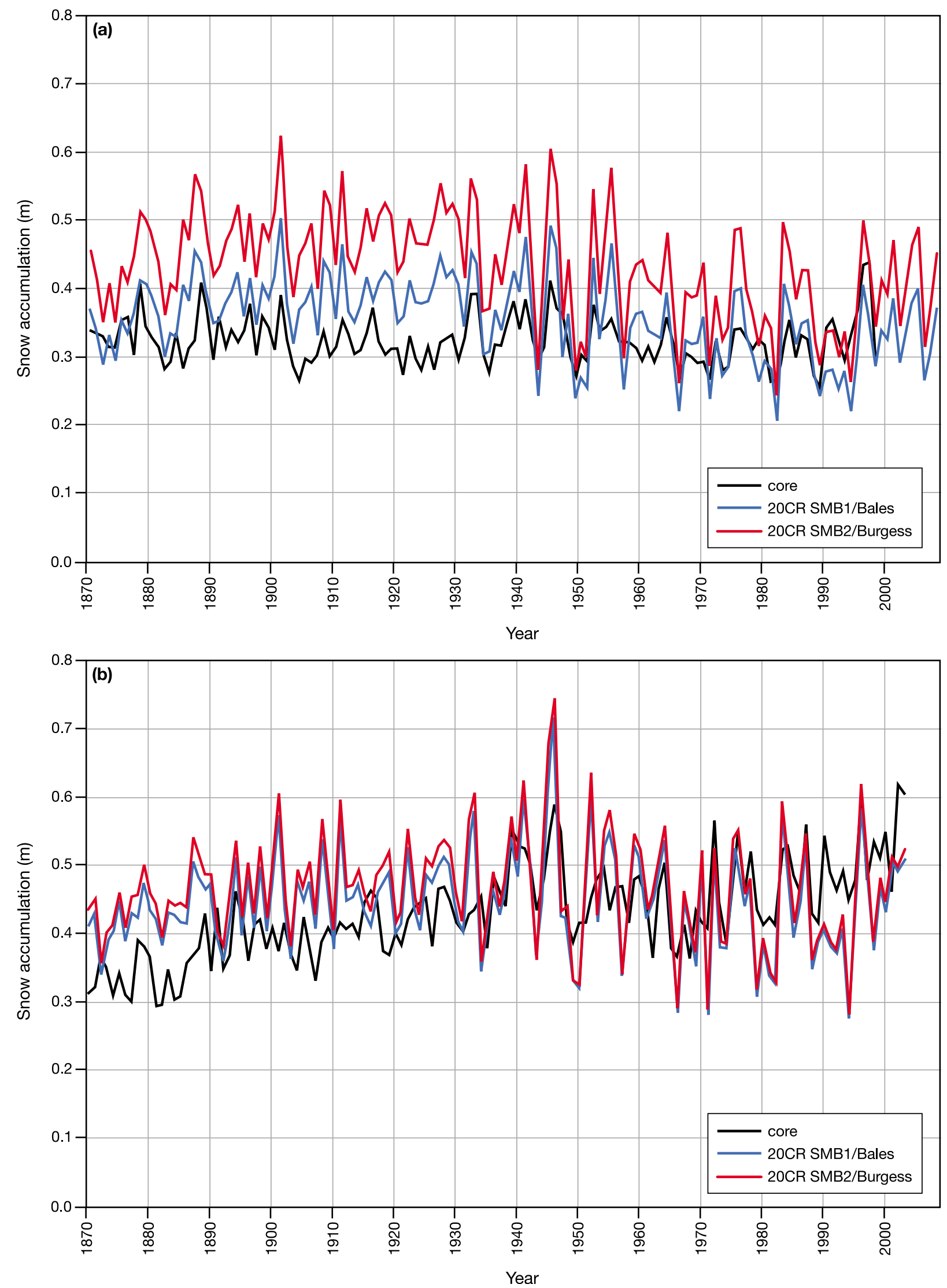

Figure 6. Comparison of mean modeled snow accumulation from $20 \mathrm{CR}$ with mean observed accumulation at (a) 18 Bales shallow ice core sites and (b) 12 McConnell shallow ice core sites. See Figure 1b for locations. 

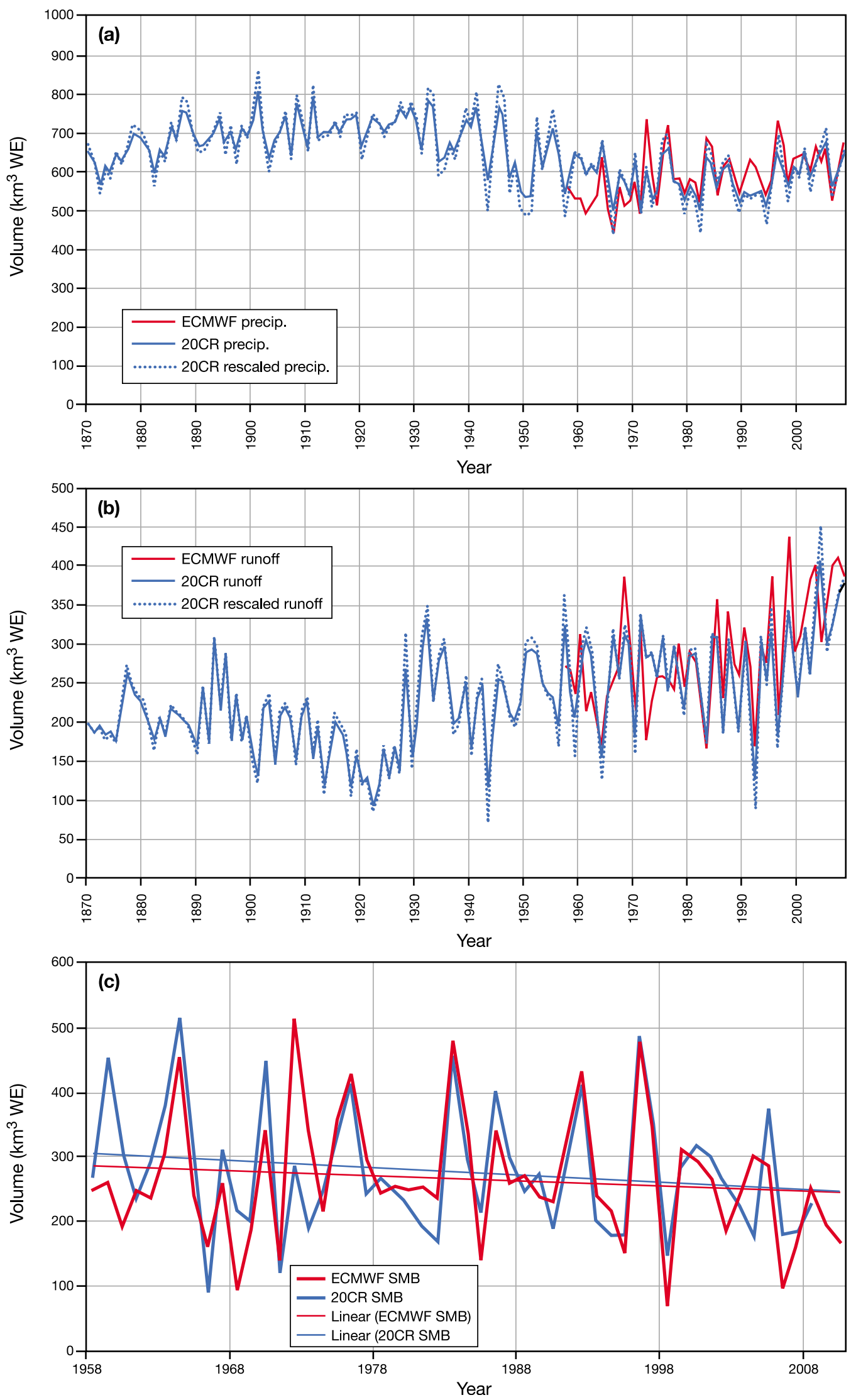

Figure 7. Comparison of (a) Greenland Ice Sheet annual mean precipitation from ECMWF and raw and rescaled 20CR analyses, (b) Greenland Ice Sheet annual mean runoff from ECMWF and raw and rescaled 20CR analyses, and (c) SMB constructed from ECMWF and 20CR analyses. 


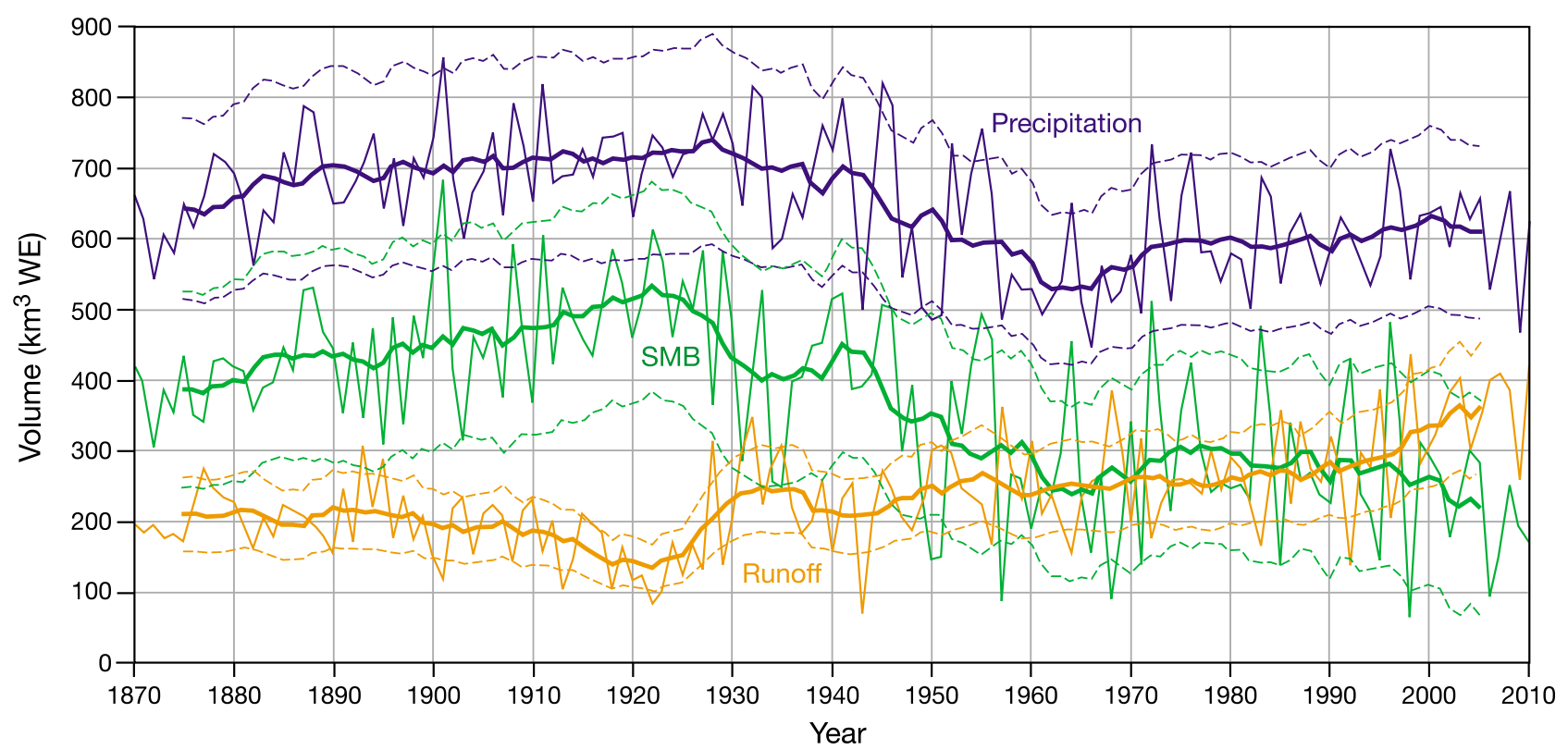

Figure 8. New Greenland Ice Sheet annual surface mass balance SMB1 series from 1870 to 2010, extended and recalibrated from Hanna et al. [2005, 2008], here based on combined Twentieth Century Reanalysis and European Centre for Medium-Range Weather Forecasts meteorological (re)analysis tuned against the Bales et al. [2009] accumulation map. The total precipitation and surface meltwater runoff components are also shown; the latter also includes any rain as runoff. Bold lines show 11 year running means, and color-coded dashed lines show uncertainty estimates in SMB and its parameters.

the mid-1960s, when it started increasing again until around 2000 , but it did not get back up to its former, early twentiethcentury levels. The 11 year running mean in Figure 8 indicates a possible slight precipitation decrease between 2000 and 2010. Meanwhile, modeled runoff has been increasing fairly steadily since the mid-1940s (although punctuated by occasional low runoff years, some of which coincide with the aftermath of large volcanic eruptions such as 1963 Agung, 1982 El Chichón, and 1991 Pinatubo), and visibly at an accelerating rate since around 1990 . Overall SMB decreased

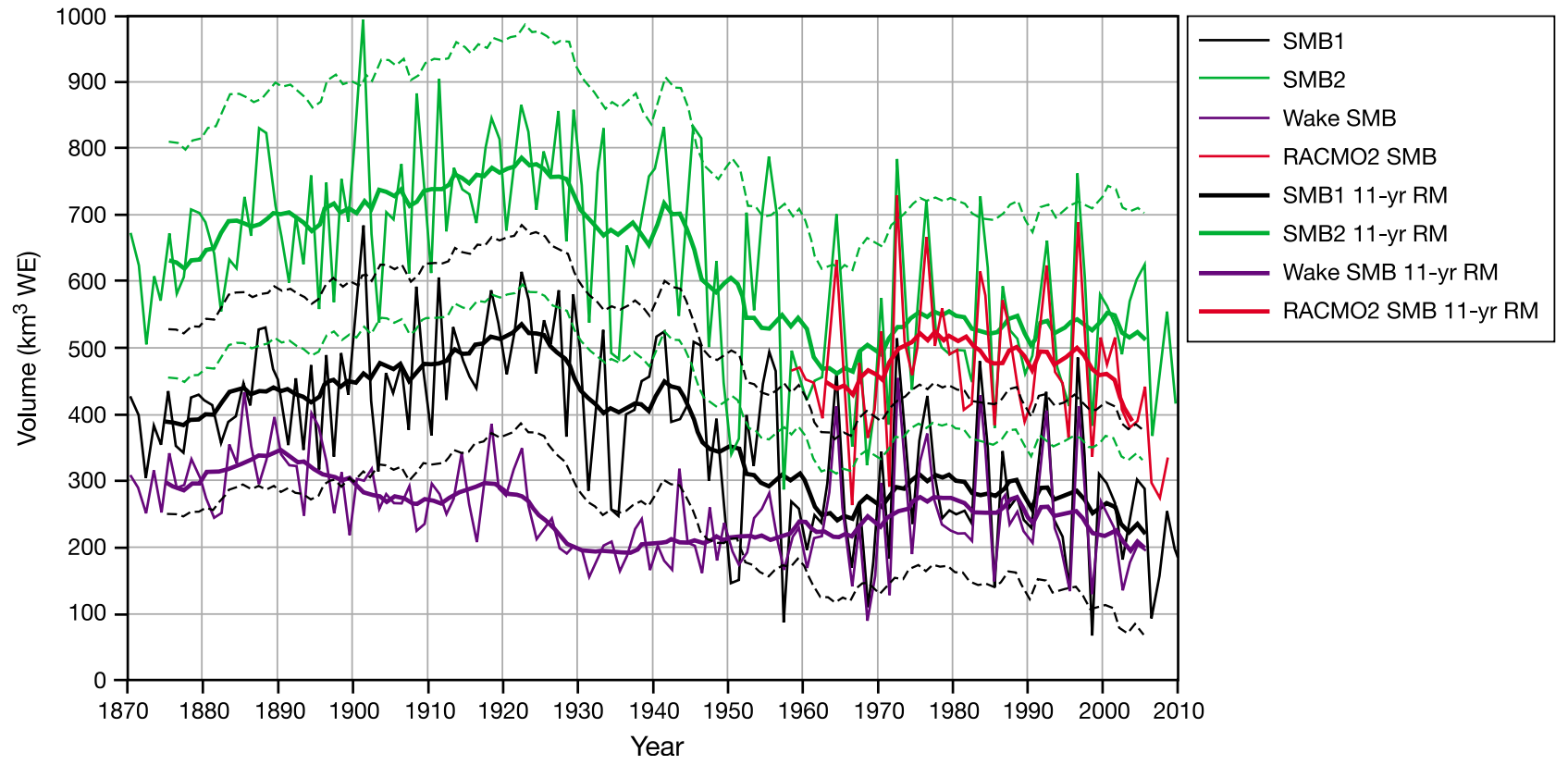

Figure 9. Comparison of four different Greenland Ice Sheet surface mass balance reconstructions: (Hybrid = ECMWF + 20CR) SMB1 and SMB2 from this study, RACMO2 SMB after Van den Broeke [2009], and Wake SMB after Wake et al. [2009]. Bold lines show 11 year running means, and colorcoded dashed lines show uncertainty estimates in SMB1 and SMB2. 
Table 5. Means, Standard Deviations, and Linear Least Squares Regression Trends in Greenland Ice Sheet SMB and Its Components for Selected Periods From Different Model Time Series Referred to in This Study ${ }^{\mathrm{a}}$

\begin{tabular}{|c|c|c|c|c|c|}
\hline Model & Period & Parameter & Mean & Standard Deviation & Trend \\
\hline \multirow[t]{7}{*}{ SMB1 (ECMWF/Bales) } & \multirow{7}{*}{ 1990-2008 } & SMB & 256 & 103 & -5.4 \\
\hline & & Precipitation & 618 & 52 & 1.5 \\
\hline & & Snowfall & 589 & 50 & 0.4 \\
\hline & & Evaporation/sublimation & 36 & 7 & -0.8 \\
\hline & & Melt & 389 & 80 & 8.4 \\
\hline & & Runoff & 327 & 75 & 7.6 \\
\hline & & Refreeze & 92 & 16 & 1.8 \\
\hline \multirow[t]{7}{*}{ SMB2 (ECMWF/Burgess) } & \multirow[t]{7}{*}{ 1990-2008 } & SMB & 533 & 104 & -1.4 \\
\hline & & Precipitation & 842 & 73 & 4.2 \\
\hline & & Snowfall & 759 & 70 & 3.4 \\
\hline & & Evaporation & 36 & 7 & -0.8 \\
\hline & & Melt & 366 & 74 & 8.2 \\
\hline & & Runoff & 273 & 63 & 6.5 \\
\hline & & Refreeze & 140 & 28 & 3.3 \\
\hline \multirow[t]{7}{*}{ RACMO2 } & \multirow[t]{7}{*}{ 1990-2008 } & SMB & 444 & 108 & -10.3 \\
\hline & & Precipitation & 770 & 60 & -0.4 \\
\hline & & Snowfall & 717 & 57 & -1.2 \\
\hline & & Evaporation/sublimation & 28 & 3 & 0.2 \\
\hline & & Melt & 466 & 103 & 11.9 \\
\hline & & Runoff & 299 & 80 & 9.7 \\
\hline & & Refreeze & 217 & 35 & 3.1 \\
\hline \multirow{7}{*}{ SMB1 (ECMWF/Bales) } & \multirow{7}{*}{$1961-1990$} & SMB & 279 & 99 & 0.4 \\
\hline & & Precipitation & 577 & 70 & 2.5 \\
\hline & & Snowfall & 556 & 68 & 2.3 \\
\hline & & Evaporation/sublimation & 39 & 3 & 0.2 \\
\hline & & Melt & 315 & 58 & 2.4 \\
\hline & & Runoff & 259 & 54 & 1.9 \\
\hline & & Refreeze & 78 & 12 & 0.6 \\
\hline \multirow{7}{*}{ SMB2 ECMWF/Burgess) } & \multirow[t]{7}{*}{$1961-1990$} & SMB & 518 & 113 & 1.6 \\
\hline & & Precipitation & 774 & 93 & 3.3 \\
\hline & & Snowfall & 700 & 88 & 2.8 \\
\hline & & Evaporation & 39 & 3 & 0.2 \\
\hline & & Melt & 297 & 51 & 2.2 \\
\hline & & Runoff & 217 & 44 & 1.5 \\
\hline & & Refreeze & 114 & 17 & 1.0 \\
\hline \multirow[t]{7}{*}{ RACMO2 SMB } & \multirow[t]{7}{*}{$1961-1990$} & SMB & 480 & 104 & 1.2 \\
\hline & & Precipitation & 727 & 82 & 2.1 \\
\hline & & Snowfall & 685 & 78 & 1.8 \\
\hline & & Evaporation/sublimation & 26 & 2 & 0.1 \\
\hline & & Melt & 366 & 54 & 0.8 \\
\hline & & Runoff & 222 & 38 & 0.9 \\
\hline & & Refreeze & 184 & 23 & 0.3 \\
\hline
\end{tabular}

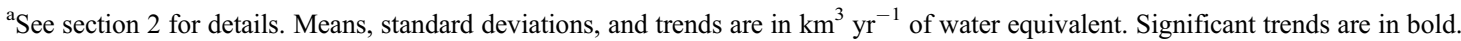

in two main phases between the early 1920s and mid-1960s and again since the early mid 1990s (at an enhanced rate since 2000).

[17] Our SMB reconstruction indicates modeled SMB trends of $-1.8(-1.7) \mathrm{km}^{3} \mathrm{yr}^{-1}$ for SMB1 (SMB2) for 18712010, which are statistically highly significant (Table 6). Modeled precipitation trends are $-0.9(-1.0) \mathrm{km}^{3} \mathrm{yr}^{-1}$, and modeled runoff trends are $1.1(0.9) \mathrm{km}^{3} \mathrm{yr}^{-1}$ for SMB1 (SMB2) for the same period; all these trends are significant (Table 6). In part this is related to Greenland's colder climate during the late nineteenth and early twentieth centuries [Box et al., 2009], which was evidently wetter/snowier on average for the whole island, although further checking needs to be done against ice core and climate-station data to fully verify this finding.

[18] For 1990-2008, modeled runoff increases by $7.6(6.5) \mathrm{km}^{3} \mathrm{yr}^{-1}$ for SMB1 (SMB2) but there is a greater disagreement of modeled precipitation between the two series, with SMB1 (SMB2) increasing by $1.5(4.2) \mathrm{km}^{3} \mathrm{yr}^{-1}$ during this period; this results in a simulated SMB1 (SMB2) decrease of $-5.4(-1.4) \mathrm{km}^{3} \mathrm{yr}^{-1}$ (Table 5). We attribute this
1990-2008 SMB trend difference to differences in the sensitivity of our SMB1 and SMB2 precipitation reconstructions to regionally variable trends, especially in the higher accumulation zone of southeast Greenland. The much greater SMB decrease in SMB1 for this period reflects a combination of a lower precipitation (or accumulation) increase and a higher runoff increase in SMB1 compared with SMB2. The model is very sensitive (as in the real world) to precipitation changes: if precipitation increases (or at a greater rate, as with SMB2), runoff kicks in later in the season and therefore decreases owing to the ice-albedo feedback. If we consider just the difference in the precipitation trends, the difference between SMB1 and SMB2, although still significant, is only $\sim 2.7 \mathrm{~km}^{3} \mathrm{yr}^{-1}$ over the same period.

\subsection{Comparison of New and Existing Published SMB Time Series}

[19] We present a comparison of our SMB1 and SMB2 annual time series against two other GrIS SMB series from RACMO2.1/GR [Van den Broeke et al., 2009] and the interpolated SMB series (based on extrapolation from coastal 
Table 6. Means, Standard Deviations, and Linear Least Squares Regression Trends in Greenland Ice Sheet SMB and Its Main Components for Selected Periods From SMB1 and SMB2 (20CR + ECMWF-Based) Model Time Series Referred to in This Study ${ }^{\mathrm{a}}$

\begin{tabular}{|c|c|c|c|c|c|}
\hline Model & Period & Parameter & Mean & Standard Deviation & Trend \\
\hline \multirow[t]{3}{*}{ SMB1 (20CR + ECMWF/Bales) } & \multirow[t]{3}{*}{$1871-2010$} & SMB & 368 & 129 & -1.8 \\
\hline & & Precipitation & 648 & 89 & -0.9 \\
\hline & & Runoff & 236 & 75 & 1.1 \\
\hline \multirow{3}{*}{ SMB2 (20CR + ECMWF/Burgess) } & \multirow{3}{*}{$1871-2010$} & SMB & 622 & 144 & -1.7 \\
\hline & & Precipitation & 866 & 118 & -1.0 \\
\hline & & Runoff & 199 & 62 & 0.9 \\
\hline \multirow{3}{*}{ SMB1 (20CR/Bales) } & \multirow{3}{*}{$1871-1900$} & SMB & 416 & 65 & 2.8 \\
\hline & & Precipitation & 672 & 60 & 3.3 \\
\hline & & Runoff & 207 & 38 & 0.2 \\
\hline \multirow[t]{3}{*}{ SMB2 (20CR/Burgess) } & \multirow[t]{3}{*}{$1871-1900$} & SMB & 668 & 84 & 4.0 \\
\hline & & Precipitation & 891 & 83 & 4.4 \\
\hline & & Runoff & 175 & 32 & 0.1 \\
\hline \multirow[t]{3}{*}{ SMB1 (20CR/Bales) } & \multirow[t]{3}{*}{$1901-1930$} & SMB & 495 & 85 & 2.1 \\
\hline & & Precipitation & 720 & 55 & 1.0 \\
\hline & & Runoff & 171 & 52 & -1.3 \\
\hline \multirow{3}{*}{ SMB2 (20CR/Burgess) } & \multirow{3}{*}{ 1901-1930 } & SMB & 756 & 97 & 2.0 \\
\hline & & Precipitation & 957 & 77 & 1.3 \\
\hline & & Runoff & 146 & 43 & -0.9 \\
\hline \multirow[t]{3}{*}{ SMB1 (20CR + ECMWF/Bales) } & \multirow{3}{*}{$1931-1960$} & SMB & 362 & 123 & -4.7 \\
\hline & & Precipitation & 648 & 109 & -5.1 \\
\hline & & Runoff & 245 & 61 & 0.4 \\
\hline \multirow{3}{*}{ SMB2 (20CR + ECMWF/Burgess) } & \multirow{3}{*}{$1931-1960$} & SMB & 612 & 157 & -6.3 \\
\hline & & Precipitation & 861 & 149 & -6.5 \\
\hline & & Runoff & 208 & 51 & 0.4 \\
\hline
\end{tabular}

${ }^{\mathrm{a}}$ See section 2 for details. Means, standard deviations, and trends are in $\mathrm{km}^{3} \mathrm{yr}^{-1}$ of water equivalent. Significant trends are in bold.

station meteorological and ice core, i.e., nongridded, data for the pre-1958 period) of Wake et al. [2009] (Figure 9 and Table 6). Several features to note are (1) the good qualitative and quantitative agreement in relative SMB changes between all four series during the common (1958-2008) overlap period (Figures 9 and 10), which gives some confidence that the relative changes are being modeled with a degree of skill; (2) the large discrepancies in absolute SMB values between the various time series, which is mainly related to differences in the precipitation base maps used; and (3) the discrepancy between our new and the Wake et al. [2009] SMB series for the pre-1958 period. Wake et al. [2009] SMB is relatively low compared with the other SMB series values because it was created using the precipitation base map reported by Janssens and Huybrechts [2000], which later work [Bales et al., 2009; Burgess et al., 2010; Ettema et al., 2009] has shown probably underestimates high precipitation and accumulation areas around the ice sheet margins. The Wake et al. [2009] SMB time series also has a much longer stable period during the twentieth century and drops down in the early part of the series much earlier (1890-1930), when our SMB1/2 series are rising (Figure 9). We attribute this difference primarily to differences in the spatiotemporal pattern of Box's climate reconstruction and 20CR rather than methodological differences in applying the climate forcing (anomaly forcing of Wake et al. [2009] versus direct forcing in the present study) because Wake SMB and SMB1 agree really well for the post-1958 period, when common ECMWF reanalysis data were used to generate both $\mathrm{SMB}$ series. As well as significant differences in precipitation for the period prior to 1958 , there are also $\sim 100 \mathrm{~km}^{3}$ differences in the runoff series of Wake et al. [2009] (not shown here), which starts off at $\sim 250 \mathrm{~km}^{3}$ and gradually increases to close to $400 \mathrm{~km}^{3}$ at around 1935. In our SMB1 and SMB2 data sets, runoff actually declines slightly during most of this period (Figure 8). Again this is most likely owing to differences between J. Box's climate data and 20CR.

[20] There are very significant variations in the rate of the post-1990 SMB decrease between the various model estimates: SMB1 gives $-5.4 \mathrm{~km}^{3} \mathrm{yr}^{-1}$, SMB2 gives only $-1.4 \mathrm{~km}^{3} \mathrm{yr}^{-1}$ but RACMO2.1/GR gives some $-10.3 \mathrm{~km}^{3}$ $\mathrm{yr}^{-1}$ for the same 1990-2008 period. This is related to SMB1 and SMB2 showing substantial precipitation increases (statistically significant for SMB2) whereas RACMO2.1/GR shows a small (nonsignificant) precipitation decrease, and also to runoff increases being somewhat less (although still significant) in SMB1 and SMB2 compared with RACMO2.1/GR (Table 5). Mean precipitation is much higher for SMB2 (based on Burgess et al. [2010] accumulation data) than SMB1 (based on Bales et al. [2009] accumulation data) (Tables 3 and 4). This spread of model estimates is largely due to an almost complete lack of validation data and resulting uncertainties in southeast Greenland where accumulation rates are greatest and gradients steepest, as highlighted, for example, by Van den Broeke et al. [2009] and Ettema et al. [2009]. The SMB1 (SMB2) series underestimates (overestimates) precipitation with respect to RACMO2.1/GR, but SMB2 precipitation is closer than SMB1 precipitation to RACMO precipitation (Table 5 and Figure 10d).

[21] Spatial trends in our SMB1 annual series are shown in Figure 11 for 1870-2010 and 1990-2010; these show an overall linear least squares regression line trend in meters per year for the respective time periods. SMB1 increased by several tens of $\mathrm{cm}$ in total for much of the interior southern and eastern parts of the ice sheet during 1870-2010, but increases were more localized and generally further toward the central and northern parts of the GrIS during 1990-2010, 

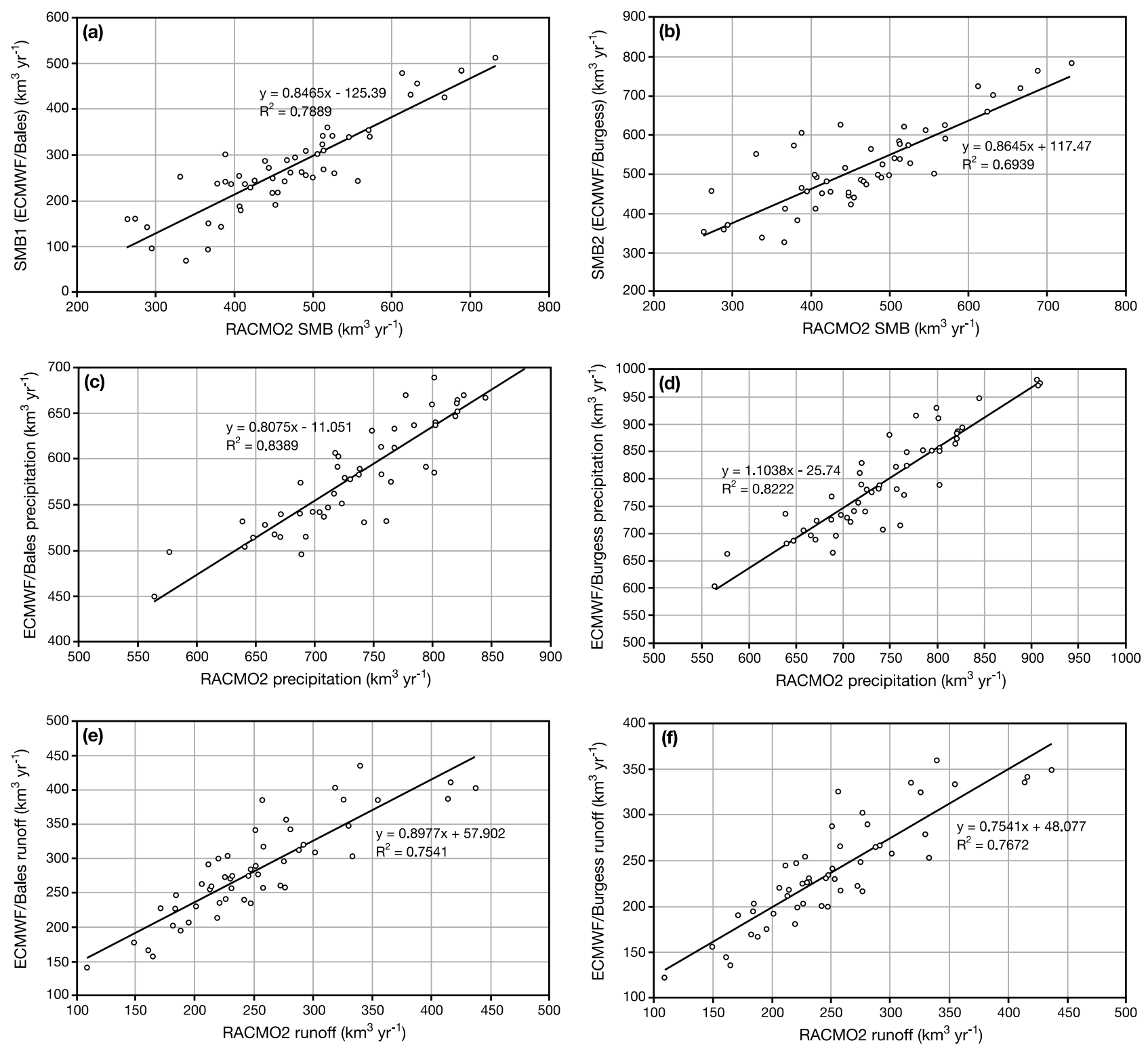

Figure 10. Regression of (a) SMB1 versus RACMO2 SMB, (b) SMB2 versus RACMO2 SMB, (c) ECMWF/Bales precipitation versus RACMO2 precipitation, (d) ECMWF/Burgess precipitation versus RACMO2 precipitation, (e) ECMWF/Bales runoff versus RACMO2 runoff, and (f) ECMWF/Burgess runoff versus RACMO2 runoff, all for the common overlap (1958-2008) period.

probably owing to recent climate warming over Greenland [Hanna et al., 2008; Box et al., 2010]. Rates of modeled SMB loss are widely several times greater in southern Greenland in 1990-2010 but there are also distinct local areas of SMB gain in the south during this time period. This kind of map is useful for comparing with the surface-elevation signal from satellite altimetry, which can be done as part of future work.

\section{Comparison of SMB With Climatic Indices and Forcing Factors}

[22] We compared our new GrIS Hybrid SMB series with Greenland and hemispheric temperature variations,
North Atlantic Oscillation (NAO), El Nino Southern Oscillation (ENSO) and Pacific Decadal Oscillation (PDO) indices, as well as the International Ice Patrol's (IIP) North Atlantic iceberg flux at $48^{\circ} \mathrm{N}$ [e.g., Marko et al., 1994], for 1870-2009 and two more recent subperiods (Table 7). North Atlantic iceberg flux at $48^{\circ} \mathrm{N}$ is regarded as a proxy for net Greenland iceberg flux on account of the prevailing Labrador Current which carries icebergs southward from the Greenland region south past Newfoundland. The PDO and ENSO, although emphasizing atmosphere-ocean interaction in different regions of the Pacific, are known to be intimately connected [Newman et al., 2003; Newman, 2007]. There is no significant correlation between the iceberg flux and total ice sheet SMB, precipitation or runoff for any of the periods, 

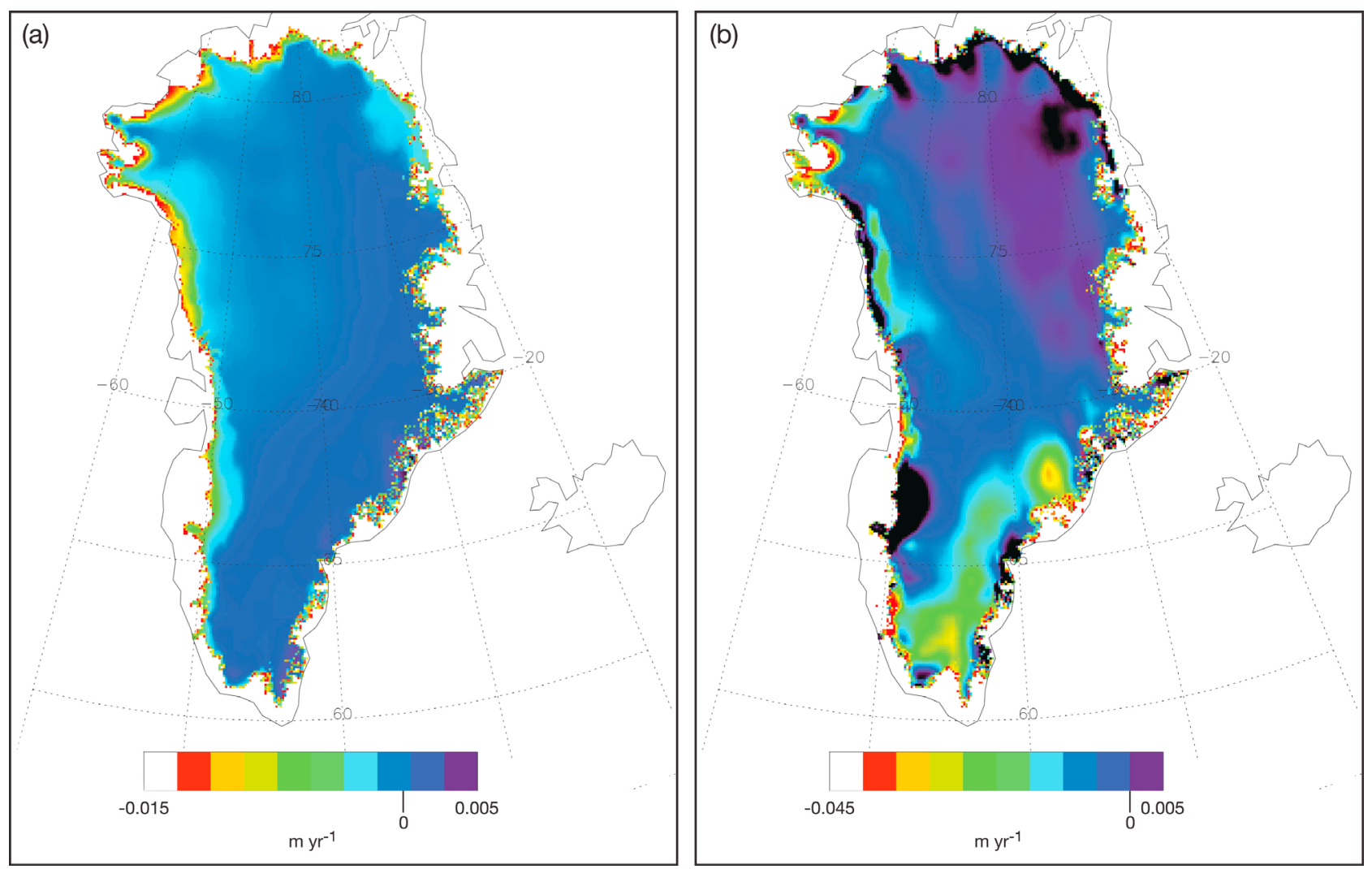

Figure 11. Linear least squares regression trends of GrIS SMB1 for (a) 1870-2010 and (b) 1990-2010. Note the different scales and regional/temporal disparities of change.

which suggests either a complex relationship between SMB variability and calving variability and/or subsequent modification by contemporaneous and subsequent atmospheric and oceanic circulation changes [Hanna et al., 2009]. Any SMBiceberg flux correlation would most likely have a lag, as it would take at least a year for icebergs to get to $48^{\circ} \mathrm{N}$, and there will be a lag from accumulation to coastal discharge too, which would smooth the temporal correlation. We therefore also investigated lead/lag relationships of iceberg numbers with runoff for leads and lags of both 5 and 11 year smoothed data series of up to five years, again with no significant correlations whatsoever. However, there is a significant $(\mathrm{p} \leq 0.01)$ correlation of iceberg numbers with the annual NAOI ( $\mathrm{r}=0.36$ between both detrended time series), which might reflect lower temperatures in the Davis Strait in a positive NAO preserving icebergs, with resulting longer travel distances. Also, a spatial correlation analysis of the iceberg numbers versus runoff suggests no relation whatsoever for the bulk of the ice sheet except for some pixels right at the margin of the ice sheet that show a positive correlation, which suggests that some local increases in runoff are associated with higher North Atlantic iceberg numbers (Figure 12a). However, the NAO-iceberg hypothesis, and a more thorough analysis of the SMB-iceberg link, requires further investigation.

[23] Northern Hemisphere temperature is significantly positively correlated $(\mathrm{r}=0.38-0.42)$ with runoff (for all three periods) and significantly negatively correlated with SMB $(\mathrm{r}=-0.20$ to -0.29$)$ but not significantly correlated with modeled Greenland precipitation (Table 7). NAO exhibits some significant negative correlations with runoff (but only at $r \sim-0.3$ ), which may be explained by more positive NAO tending to be associated with lower temperatures around southwest coastal Greenland [Hanna and Cappelen, 2003]. Perhaps unsurprisingly, given the selective modest but significant correlations between whole-Greenland SMB and NAO, there are no significant correlations between Greenland SMB, precipitation or runoff and ENSO or PDO (the latter two are not shown in Table 7). However, when taking the GrIS pixel by pixel, strong spatial variations in the otherwise modest GrIS SMB-NAO correlations become evident, with significant negative correlations over much of central Greenland, especially toward the west, and converse positive correlations near the outer ice margin (Figure 12b). This could reflect relatively low accumulation inland with more negative SMB values, and relatively low runoff (hence more positive SMB values) around the GrIS margins, both being associated with a positive $\mathrm{NAO}$, in line with colder, presumably drier conditions during positive NAO intimated by Hanna and Cappelen [2003], but we leave detailed analysis of this relationship to future work. Regarding Greenland station temperatures, the correlations are strongest (significantly positive, $r \sim 0.5-0.7$ ) with modeled runoff (partly explained by ECMWF output temperatures being validated against station data before their use in the runoff model), with a couple of significant negative correlations between Ilulissat 
Table 7. Correlation Coefficients Between Detrended Greenland Ice Sheet SMB and Its Components, Tuned Against the Bales et al. [2009] Accumulation Map and Various Detrended Climatic Indices $^{\mathrm{a}}$

\begin{tabular}{lcrrr}
\hline Parameter & Period & Precipitation & Runoff & SMB \\
\hline Iceberg flux at 48 $\mathrm{N}$ & $1900-2009$ & 0.12 & -0.02 & 0.09 \\
& $1950-2009$ & 0.05 & -0.08 & 0.07 \\
& $1980-2009$ & 0.03 & -0.02 & 0.03 \\
HadCRUT3v Northern & $1870-2010$ & -0.01 & $\mathbf{0 . 3 8}$ & $-\mathbf{0 . 2 0}$ \\
Hemisphere temperature & & & & \\
& $1950-2010$ & -0.11 & $\mathbf{0 . 4 2}$ & $-\mathbf{0 . 2 9}$ \\
& $1980-2010$ & -0.02 & $\mathbf{0 . 4 0}$ & -0.28 \\
North Atlantic Oscillation & $1870-2009$ & -0.03 & $-\mathbf{0 . 2 9}$ & 0.13 \\
Index (annual) & & & & \\
& $1950-2009$ & 0.03 & -0.24 & 0.15 \\
NAOI (Jun, Jul, Aug) & $1980-2009$ & -0.20 & -0.29 & 0.06 \\
& $1870-2010$ & 0.16 & $-\mathbf{0 . 3 0}$ & $\mathbf{0 . 2 9}$ \\
& $1950-2010$ & 0.18 & -0.24 & 0.25 \\
NAOI (Jan, Feb, Mar) & $1980-2010$ & 0.16 & -0.13 & 0.18 \\
& $1870-2010$ & -0.03 & -0.09 & 0.01 \\
& $1950-2010$ & 0.00 & -0.15 & 0.06 \\
NAOI (Oct, Nov, Dec) & $1980-2010$ & -0.21 & -0.23 & 0.00 \\
& $1870-2010$ & -0.05 & -0.13 & 0.03 \\
NAOI (Oct, Nov, Dec) & $1950-2010$ & 0.02 & -0.13 & 0.08 \\
04221 Ilulissat & $1980-2010$ & 0.07 & -0.15 & 0.14 \\
air temperature & $1870-2010$ & -0.14 & $\mathbf{0 . 4 9}$ & $-\mathbf{0 . 3 8}$ \\
& & & & \\
& $1950-2010$ & $-\mathbf{0 . 3 6}$ & $\mathbf{0 . 7 2}$ & $-\mathbf{0 . 6 5}$ \\
04250 Nuuk air temperature & $1980-2010$ & -0.12 & $\mathbf{0 . 7 0}$ & $-\mathbf{0 . 5 4}$ \\
& $1870-2010$ & -0.06 & 0.09 & -0.09 \\
34262/04270 & $1980-2010$ & -0.22 & $\mathbf{0 . 6 2}$ & $-\mathbf{0 . 4 8}$ \\
Ivittuut/Narsarsuaq & $1870-2010$ & -0.05 & $\mathbf{0 . 6 9}$ & $-\mathbf{0 . 4 2}$ \\
& & & 0.07 & -0.07 \\
04360 Tasiilaq & $1950-2009$ & $-\mathbf{0 . 2 6}$ & $\mathbf{0 . 5 1}$ & $-\mathbf{0 . 4 4}$ \\
& $1980-2009$ & 0.08 & $\mathbf{0 . 4 5}$ & -0.24 \\
& $1870-2010$ & & & \\
& $1950-2009$ & -0.11 & $\mathbf{0 . 5 6}$ & $-\mathbf{0 . 3 7}$ \\
& $1980-2009$ & -0.03 & $\mathbf{0 . 4 7}$ & -0.32 \\
\hline
\end{tabular}

${ }^{\mathrm{a}}$ Correlation coefficients significant at the $p \leq 0.05$ level are in bold.

and Ivittuut/Narsarsuaq temperatures and modeled Greenland precipitation for the 1950-2010 period. Therefore, there are quite a few strongly/significantly negative correlations $(\mathrm{r} \sim-0.4$ to -0.6$)$ between the Greenland station temperatures and modeled SMB. Of course, the Greenland climatestation-modeled SMB relations are partly to be expected owing to the nature of the SMB modeling using a degree-day runoff model (which is highly dependent on summer and annual temperatures) as its basis.

\section{Impact of GrIS SMB Variations on Global Sea Level Change}

[24] Global sea level equivalent for a given year equals

$$
\operatorname{SLE}(\mathrm{t})=-(\mathrm{dV} * \mathrm{dt}) / \text { Aocean }
$$

where $\operatorname{SLE}(\mathrm{t})$ is a sea level equivalent for a given time period $\mathrm{t}, \mathrm{dV}$ is SMB rate $\left(\mathrm{km}^{3}\right.$ w.e. $\left.\mathrm{yr}^{-1}\right)$ as extrapolated from Figures 8 and 9, $\mathrm{dt}$ is a time difference, and Aocean is the area of the ocean (commonly taken as $362 \times 10^{6} \mathrm{~km}^{2}$ [e.g., Parker, 1980]).

[25] Our modeled SMB trends of $-1.8(-1.7) \mathrm{km}^{3} \mathrm{yr}^{-1}$ for SMB1 (SMB2) for 1871-2010 correspond to a global sea level equivalent (SLE) of $\sim 0.49 \times 10^{-3} \mathrm{~mm} \mathrm{yr}^{-1}$ or $\sim 0.7 \mathrm{~mm}$ in total for the whole period, which appears to be due in roughly equal parts (first order) to both a decrease in modeled precipitation and an increase in modeled runoff. However, this cannot be directly translated into global sea level change without first defining an equilibrium state for the ice sheet, previously variously defined as $1961-1990$ or on occasion 1971-1988 [Wake et al., 2009; Rignot et al., 2008], as a baseline against which SMB changes can be compared (SMB deviations relative to this period would then cause sea level change); the common baseline period also allows comparison between different modeling methods. Using the 1961-1990 baseline period consistent with most earlier work implies a generally growing ice sheet until about 1960. There may be an additional significant contribution from solid ice mass flux across the grounding line (and resulting iceberg calving), which could be of the same order of magnitude as the runoff losses [Van den Broeke et al., 2009] but is very poorly constrained for the presatellite era, with only a few direct measurements of ice discharge available from before 1996 and fragmentary satellite observations since then [Rignot et al., 2008]. However, there is limited physical ground to assume that SMB changes correlate directly with calving changes (which we indicate through comparison of SMB variations with iceberg numbers in section 4). Although we leave further consideration of this aspect to a future study, we point out that owing to icedynamical changes, which can potentially be influenced by SMB changes [Zwally et al., 2002; Joughin et al., 2008; Sundal et al., 2011] but for which we have scant evidence of any such relationship in this study, the real contribution from Greenland to global sea level change over the last 140 years is likely to be significantly different from that calculated above using the SMB trends alone. Nevertheless, even if we increase it by several times, a sea level equivalent trend of $0.49 \times 10^{-3} \mathrm{~mm} \mathrm{yr}^{-1}$ from GrIS SMB changes is a very small component of the total global sea level rise, which was averaging $\sim 1.7 \mathrm{~mm} \mathrm{yr}^{-1}$ during most of this period, increasing to $\sim 3.4 \mathrm{~mm} \mathrm{yr}^{-1}$ since about 1993 [Church and White, 2006; Nerem et al., 2010]. However, modeled SMB losses accelerated significantly during recent years, estimated by this study to be between -1.4 and $-5.4 \mathrm{~km}^{3} \mathrm{yr}^{-1}$ for 1990-2008, that is, 0.0039-0.015 $\mathrm{mm} \mathrm{yr}^{-1}$ SLE during this later period, compared with an estimated $0.028 \mathrm{~mm} \mathrm{yr}^{-1}$ SLE for RACMO 2 for the same period. Again, this will have been exacerbated by ice dynamical losses in the last $5-15$ years reported by Rignot et al. [2008] and, most recently, by Rignot et al. [2011]. Rignot et al. [2011] use a variety of satellite (InSAR and GRACE) and SMB modeling to estimate a total mass balance loss from the GrIS of $\sim-150 \mathrm{~km}^{3} \mathrm{yr}^{-1}$ $\left(\sim 0.4 \mathrm{~mm} \mathrm{yr}^{-1} \mathrm{SLE}\right)$ in 2001 that increased to $<\sim-250 \mathrm{~km}^{3}$ $\mathrm{yr}^{-1}\left(\sim 0.7 \mathrm{~mm} \mathrm{yr}^{-1}\right.$ SLE) by 2010. Zwally [2011] using ICESat radar altimetry data report a GrIS net balance of $-171 \mathrm{~km}^{3} \mathrm{yr}^{-1}$ for 2003-2007. Recalculating linear least squares regression trends from our annual SMB data, for the most recent decade 2001-2010 yields modeled net SMB losses of -7.2 (SMB1) or -10.7 (SMB2) $\mathrm{km}^{3} \mathrm{yr}^{-1}$, which equates to $\sim 0.02-0.03 \mathrm{~mm} \mathrm{yr}^{-1}$ SLE, from SMB losses alone. Although SMB appears to be only a relatively modest part of the overall mass loss, further work should make use of our long-running GrIS SMB time series to compare with tide-gauge measurements of global sea level rise and other 

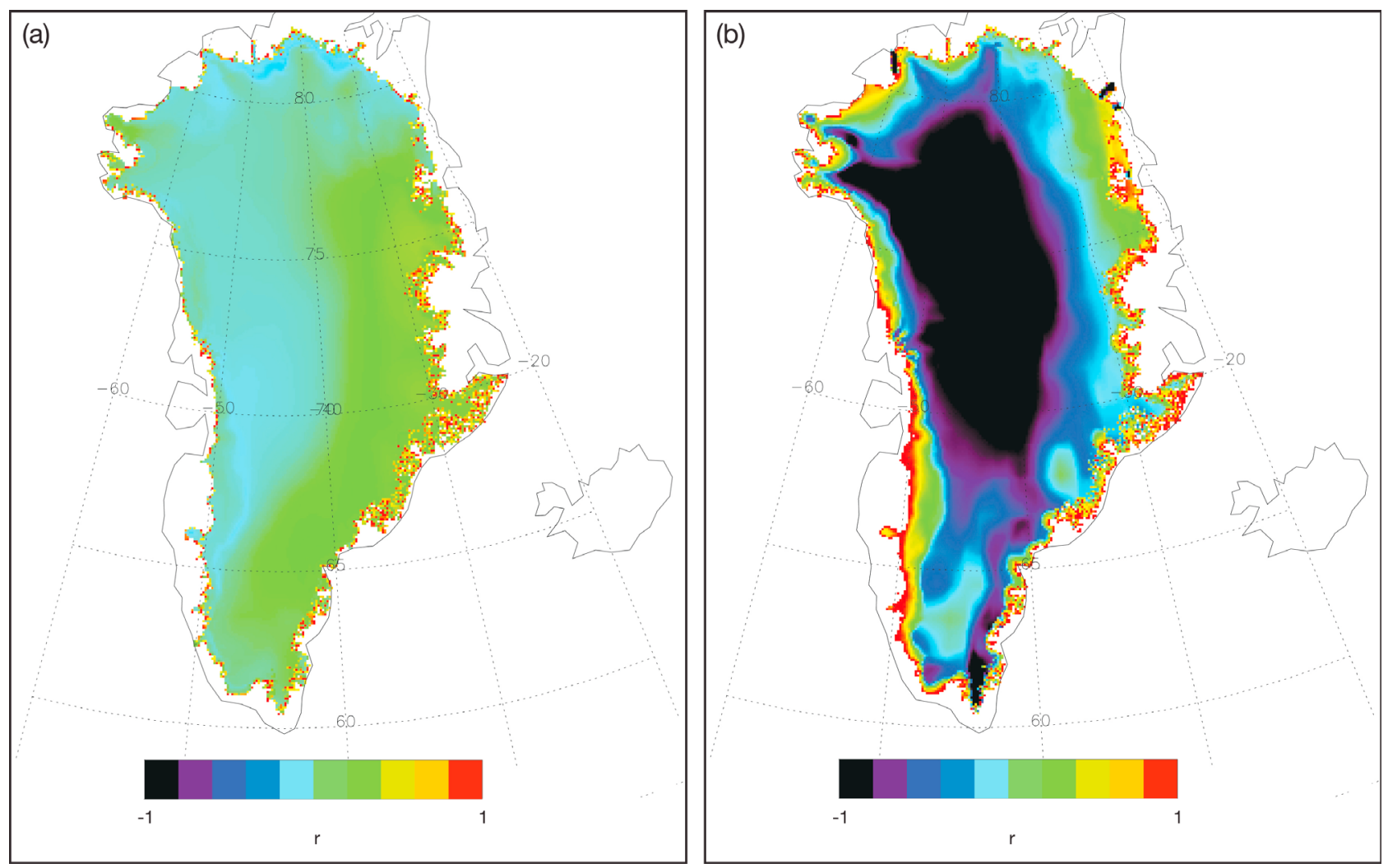

Figure 12. Correlation coefficients between (a) 1900-2009 annual GrIS runoff and annual North Atlantic iceberg count at $48^{\circ} \mathrm{N}$ (see section 4 for explanation) and (b) 1981-2010 annual GrIS SMB and annual Hurrell PC-based NAO index data.

key contributors to this change (most notably the Antarctic Ice Sheets and worldwide glaciers as well as oceanic thermal expansion) during the past century.

\section{Conclusions}

[26] We have demonstrated significant skill of the new 20CR reanalysis meteorological fields (suitably downscaled, postprocessed, and validated) in reproducing interannual climatic variability over Greenland, and therefore their use in downscaling efforts to model the ice sheet's surface mass balance for the past 140 years. We have thus effectively doubled the available/published length of modeled SMB on the basis of a homogeneous gridded climatic data set and single runoff/SMB model configuration. The two SMB time series developed in this study were calibrated for internal consistency by tuning the variances of 20CR-based downscaled precipitation and runoff fields to match those of downscaled ECMWF analyses (for GrIS averages) for the common overlap period. The resulting 1871-2010 SMB and constituent (e.g., accumulation and runoff) time series, available on a $5 \times 5 \mathrm{~km}$ Greenland grid and monthly as well as annually (only annual output are shown here), can be used in future projects for a variety of purposes, including assessing the sensitivity of mass balance to climatic changes, for example, in coming out of the Little Ice Age during the late Nineteenth Century and for studying the Greenland Warm Period of the late 1920s/early 1930s. Preliminary analysis has shown significant differences in modeled SMB depending on how accumulation is regionally calibrated, and owing to lack of validation data in key areas of southeast Greenland, there is as yet no firm solution showing which is the more accurate of the two accumulation maps used here. This remaining uncertainty regarding southeast Greenland accumulation is a key factor contributing to significantly different absolute SMB values produced by various studies (e.g., the ongoing GRIMICE SMB comparison project, J. Bamber, personal communication, 2009), and provides an urgent impetus to further in situ fieldwork programs that are currently addressing (or plan to address) this deficiency.

[27] Nevertheless, a significant decrease in SMB and increase in runoff are evident from around the mid-Twentieth Century and, as well as quantifying these trends, we have shown them to have increased in the last 10 years compared with the preceding 30-40 years (cf. running mean trends in Figures 8 and 9). Our SMB series also indicate a major decline in SMB between the mid-1920s and early-1960s, which is restricted to the 1920s in the Wake et al. [2009] SMB series owing to differences in our respective precipitation and runoff reconstructions for the early mid Twentieth Century, that - despite the results of the validation presented in the current study - remain to be fully resolved. However, the use of a consistent climatic forcing data set, gridded for the whole of Greenland, and uniform downscaling method for the entire study period, as well as the similarity in relative SMB changes between all four SMB series from independent models (Figure 9), lends some confidence to our new SMB reconstructions. 
[28] Further work should combine our results with improved and extended estimates of ice discharge (E. Rignot, personal communication, 2010) to reanalyze and extend those results from the last $\sim 50$ to 140 years, which will help reevaluate the complex relationship between GrIS SMB and ice-dynamical changes by means of this significantly longer time span. It is also envisaged that our extended SMB record will be of use and interest in global sea level analyses and more detailed Greenland climate studies as well as to help interpret radar and LIDAR surface-elevation surveys of the ice sheet by placing the latter in a longer-term climatic context.

[29] Acknowledgments. We thank NCAR and Doug Schuster for providing 20CR data, and for advice on 20CR we thank Gil Compo and Jeff Whitaker of NOAA/ESRL/PSD and Prashant Sardeshmukh, also of NOAA/ ESRL/PSD and CU/CIRES/CDC. Support for the Twentieth Century Reanalysis Project data set is provided by the U.S. Department of Energy, Office of Science Innovative and Novel Computational Impact on Theory and Experiment (DOE INCITE) program and Office of Biological and Environmental Research (BER), and by the National Oceanic and Atmospheric Administration Climate Program Office. We also thank the British Atmospheric Data Centre for providing ECMWF (re)analysis data and the IIP for iceberg-count data. We acknowledge support from NSF's Office of Polar Programs and NASA's Cryospheric Processes Program, and we thank students and staff from a number of ice core laboratories and field campaigns for assistance in developing the ice core accumulation records. We also thank Bo Vinther for sharing $\delta^{18} \mathrm{O}$ ice core data. NAO Index data were obtained from J. Hurrell's Web site at the Climate Analysis Section, NCAR, Boulder, Colorado; PDO data are from the University of Washington; and Northern Hemisphere temperature and ENSO data are from the Climatic Research Unit, UK. G.R.B. and E.H. acknowledge support from UK NERC grant NE/H023402/1. Paul Coles helped to draw figures.

\section{References}

Bales, R. C., Q. Guo, D. Shen, J. R. McConnell, G. Du, J. F. Burkhart, V. B. Spikes, E. Hanna, and J. Cappelen (2009), Annual accumulation for Greenland updated using ice core data developed during 2000-2006 and analysis of daily coastal meteorological data, J. Geophys. Res., 114, D06116, doi:10.1029/2008JD011208.

Box, J. E. (2002), Survey of Greenland instrumental temperature records: 1873-2001, Int. J. Climatol., 22, 1829-1847, doi:10.1002/joc.852.

Box, J. E., D. H. Bromwich, B. A. Veenhuis, L.-S. Bai, J. C. Stroeve, J. C. Rogers, K. Steffen, T. Haran, and S.-H. Wang (2006), Greenland ice sheet surface mass balance variability (1988-2004) from calibrated Polar MM5 output, J. Clim., 19, 2783-2800, doi:10.1175/JCLI3738.1.

Box, J. E., L. Yang, D. H. Browmich, and L.-S. Bai (2009), Greenland ice sheet near-surface air temperature variability: 1840-2007, J. Clim., 22, 4029-4049, doi:10.1175/2009JCLI2816.1.

Box, J. E., J. Cappelen, D. Decker, X. Fettweis, T. Mote, M. Tedesco, and R. S. W. van de Wal (2010), Greenland, in Arctic Report Card: Update for 2010, http://www.arctic.noaa.gov/reportcard/greenland.html, NOAA, Washington, D.C.

Braithwaite, R., and O. B. Olesen (1989), Calculation of glacier ablation from air temperature, west Greenland, in Glacier Fluctuations and Climatic Change, edited by J. Oerlemans, pp. 219-288, Kluwer, Dordrecht, Netherlands.

Burgess, E. W., R. R. Forster, J. E. Box, E. Mosley-Thompson, D. H. Bromwich, R. C. Bales, and L. C. Smith (2010), A spatially calibrated model of annual accumulation rate on the Greenland Ice Sheet, J. Geophys. Res., 115, F02004, doi:10.1029/2009JF001293.

Cappelen, J. (Ed.) (2011), DMI Monthly Climate Data Collection 17682010: Denmark, The Faroe Islands and Greenland, Tech. Rep. 11-05, Dan. Meteorol. Inst., Copenhagen.

Church, J. A., and N. J. White (2006), A 20th century acceleration in global sea-level rise, Geophys. Res. Lett., 33, L01602, doi:10.1029/ 2005GL024826.

Chylek, P., M. K. Dubey, and G. Lesins (2006), Greenland warming of 1920-1930 and 1995-2005, Geophys. Res. Lett., 33, L11707, doi:10.1029/ 2006GL026510.

Compo, G. P., J. S. Whitaker, and P. D. Sardeshmukh (2006), Feasibility of a 100 year reanalysis using only surface pressure data, Bull. Am. Meteorol. Soc., 87, 175-190, doi:10.1175/BAMS-87-2-175.

Compo, G. P., et al. (2011), The Twentieth Century Reanalysis Project, Q. J. R. Meteorol. Soc., 137, 1-28, doi:10.1002/qj.776.
Ekholm, S. (1996), A full coverage, high-resolution, topographic model of Greenland computed from a variety of digital elevation data, J. Geophys. Res., 101, 21,961-21,972, doi:10.1029/96JB01912.

Ettema, J., M. R. Van den Broeke, E. van Meijgaard, W. Jan van de Berg, J. L. Bamber, J. E. Box, and R. C. Bales (2009), Higher surface mass balance of the Greenland ice sheet revealed by high-resolution climate modeling, Geophys. Res. Lett., 36, L12501, doi:10.1029/2009GL038110.

Ettema, J., M. R. van den Broeke, E. van Meijgaard, and W. J. van de Berg (2010a), Climate of the Greenland ice sheet using a high-resolution climate model - Part 2: Near-surface climate and energy balance, Cryosphere, 4, 529-544, doi:10.5194/tc-4-529-2010.

Ettema, J., M. R. van den Broeke, E. van Meijgaard, W. J. van de Berg, J. E. Box, and K. Steffen (2010b), Climate of the Greenland ice sheet using a high-resolution climate model - Part 1: Evaluation, Cryosphere, 4, 511-527, doi:10.5194/tc-4-511-2010.

Fettweis, X. (2007), Reconstruction of the 1979-2006 Greenland ice sheet surface mass balance using the regional climate model MAR, Cryosphere, 1, 21-40, doi:10.5194/tc-1-21-2007.

Fettweis, X., E. Hanna, H. Gallée, P. Huybrechts, and M. Erpicum (2008), Estimation of the Greenland ice sheet surface mass balance for the 20th and 21st centuries, Cryosphere, 2, 117-129, doi:10.5194/tc-2-117-2008.

Gregory, J. M., P. Huybrechts, and S. C. B. Raper (2004), Climatology: Threatened loss of the Greenland ice-sheet, Nature, 428, 616, doi: $10.1038 / 428616 a$.

Hanna, E., and J. Cappelen (2003), Recent cooling in coastal southern Greenland and relation with the North Atlantic Oscillation, Geophys. Res. Lett., 30(3), 1132, doi:10.1029/2002GL015797.

Hanna, E., P. Huybrechts, and T. Mote (2002), Surface mass balance of the Greenland Ice Sheet from climate analysis data and accumulation/runoff models, Ann. Glaciol., 35, 67-72, doi:10.3189/172756402781816744.

Hanna, E., P. Huybrechts, I. Janssens, J. Cappelen, K. Steffen, and A. Stephens (2005), Runoff and mass balance of the Greenland Ice Sheet: 1958-2003, J. Geophys. Res., 110, D13108, doi:10.1029/2004JD005641.

Hanna, E., J. McConnell, S. Das, J. Cappelen, and A. Stephens (2006), Observed and modelled Greenland Ice Sheet snow accumulation, 1958-2003, and links with regional climate forcing, J. Clim., 19, 344-358, doi:10.1175/JCLI3615.1.

Hanna, E., P. Huybrechts, K. Steffen, J. Cappelen, R. Huff, C. Shuman, T. Irvine-Fynn, S. Wise, and M. Griffiths (2008), Increased runoff from melt from the Greenland Ice Sheet: A response to global warming, J. Clim., 21, 331-341, doi:10.1175/2007JCLI1964.1.

Hanna, E., J. Cappelen, X. Fettweis, P. Huybrechts, A. Luckman, and M. H. Ribergaard (2009), Hydrologic response of the Greenland Ice Sheet: The role of oceanographic forcing, Hydrol. Processes, 23, 7-30, doi:10.1002/ hyp. 7090 .

Hodson, A. J., C. Boggild, E. Hanna, P. Huybrechts, H. Langford, K. Cameron, and A. Houldsworth (2011), The cryoconite ecosystem on the Greenland ice sheet, Ann. Glaciol., 51, 123-129, doi:10.3189/ 172756411795931985

Intergovernmental Panel on Climate Change (2007), Climate Change 2007: The Physical Science Basis-Contribution of Working Group I to the Fourth Assessment Report of the Intergovernmental Panel on Climate Change, edited by S. Solomon et al., Cambridge Univ. Press, New York.

Janssens, I., and P. Huybrechts (2000), The treatment of meltwater retention in mass-balance parameterizations of the Greenland ice sheet, Ann. Glaciol., 31, 133-140, doi:10.3189/172756400781819941.

Joughin, I., S. B. Das, M. A. King, B. E. Smith, I. M. Howat, and T. Moon (2008), Seasonal speedup along the western flank of the Greenland ice sheet, Science, 320, 781-783, doi:10.1126/science.1153288.

Krabill, W., et al. (2004), Greenland Ice Sheet: Increased coastal thinning, Geophys. Res. Lett., 31, L24402, doi:10.1029/2004GL021533.

Lenton, T. M., H. Held, E. Kriegler, J. W. Hall, W. Lucht, S. Rahmstorf, and H. J. Schellnhuber (2008), Tipping elements in the Earth's climate system, Proc. Natl. Acad. Sci. U. S. A., 105, 1786-1793, doi:10.1073/ pnas.0705414105.

Marko, J. R., D. B. Fissel, P. Wadhams, P. M. Kelly, and R. D. Brown (1994), Iceberg severity off eastern North America: Its relationship to sea ice variability and climatic change, J. Clim., 7, 1335-1351, doi:10.1175/1520-0442(1994)007<1335:ISOENA > 2.0.CO;2.

Mernild, S. H., G. E. Liston, C. A. Hiemstra, and J. H. Christensen (2010), Greenland Ice Sheet surface mass-balance modeling in a 131-yr perspective, 1950-2080, J. Hydrometeorol., 11, 3-25, doi:10.1175/2009JHM1140.1.

Murray, T., et al. (2010), Ocean regulation hypothesis for glacier dynamics in southeast Greenland and implications for ice sheet mass changes, J. Geophys. Res., 115, F03026, doi:10.1029/2009JF001522.

Nerem, R. S., D. P. Chambers, C. Choe, and G. T. Mitchum (2010), Estimating mean sea level change from the TOPEX and Jason altimeter missions, Mar. Geod., 33, 435-446, doi:10.1080/01490419.2010.491031. 
Newman, M. (2007), Interannual to decadal predictability of tropical and North Pacific sea surface temperatures, J. Clim., 20, 2333-2356, doi:10.1175/JCLI4165.1.

Newman, M., G. P. Compo, and M. A. Alexander (2003), ENSO-forced variability of the Pacific Decadal Oscillation, J. Clim., 16, 3853-3857, doi:10.1175/1520-0442(2003)016<3853:EVOTPD>2.0.CO;2.

Parker, S. P. (1980), McGraw-Hill Encyclopedia of Ocean and Atmospheric Sciences, 362 pp., McGraw-Hill, New York.

Reeh, N. (1991), Parameterization of melt rate and surface temperature on the Greenland ice sheet, Polarforschung, 59, 113-128.

Rignot, E., J. E. Box, E. Burgess, and E. Hanna (2008), Mass balance of the Greenland ice Sheet from 1958 to 2007, Geophys. Res. Lett., 35, L20502, doi:10.1029/2008GL035417.

Rignot, E., I. Velicogna, M. R. Van den Broeke, A. Monaghan, and J. Lenaerts (2011), Acceleration of the contribution of the Greenland and Antarctic ice sheets to sea level rise, Geophys. Res. Lett., 38, L05503, doi:10.1029/2011GL046583.

Steffen, K., and J. Box (2001), Surface climatology of the Greenland ice sheet: Greenland Climate Network 1995-1999, J. Geophys. Res., 106(D24), 33,951-33,964, doi:10.1029/2001JD900161

Sundal, A. V., A. Shepherd, P. Nienow, E. Hanna, S. Palmer, and P. Huybrechts (2009), Evolution of supra-glacial lakes across the Greenland Ice Sheet, Remote Sens. Environ., 113, 2164-2171, doi:10.1016/j.rse.2009.05.018

Sundal, A. V., A. Shepherd, P. Nienow, E. Hanna, S. Palmer, and P. Huybrechts (2011), Melt-induced speed-up of Greenland ice sheet offset by efficient subglacial drainage, Nature, 469, 521-524, doi: $10.1038 /$ nature 09740 .

Uppala, S. M., et al. (2005), The ERA-40 reanalysis, Q. J. R. Meteorol. Soc., 131, 2961-3012, doi:10.1256/qj.04.176.

Van den Broeke, M., P. Smeets, J. Ettema, C. Van der Veen, R. Van de Wal, and J. Oerlemans (2008), Partitioning of melt energy and meltwater fluxes in the ablation zone of the west Greenland ice sheet, Cryosphere, 2, 179-189, doi:10.5194/tc-2-179-2008.

Van den Broeke, M., J. Bamber, J. Ettema, E. Rignot, E. Schrama, W. van de Berg, E. van Meijgaard, I. Velicogna, and B. Wouters (2009), Partitioning recent Greenland mass loss, Science, 326, 984-986, doi:10.1126/ science. 1178176.

Van de Wal, R. S. W., and J. Oerlemans (1994), An energy balance model for the Greenland ice sheet, Global Planet. Change, 9, 115-131, doi:10.1016/0921-8181(94)90011-6.
Vinther, B. M., P. D. Jones, K. R. Briffa, H. B. Clausen, K. K. Andersen, D. Dahl-Jensen, and S. J. Johnsen (2010), Climatic signals in multiple highly resolved stable isotope records from Greenland, Quat. Sci. Rev., 29, 522-538, doi:10.1016/j.quascirev.2009.11.002.

Wake, L. M., P. Huybrechts, J. E. Box, E. Hanna, I. Janssens, and G. A. Milne (2009), Surface mass-balance changes of the Greenland ice sheet since 1866, Ann. Glaciol., 50, 178-184, doi:10.3189/172756409787769636.

Whung, P.-Y., E. S. Saltzman, M. J. Spencer, P. A. Mayewski, and N. Gundestrup (1994), Two-hundred-year record of biogenic sulfur in a south Greenland ice core, J. Geophys. Res., 99(D1), 1147-1156, doi:10.1029/93JD02732.

Zwally, H. J., W. Abdalati, T. Herring, K. Larson, J. Saba, and K. Steffen (2002), Surface melt-induced acceleration of Greenland ice-sheet flow, Science, 297, 218-222, doi:10.1126/science.1072708.

Zwally, H. J., et al. (2011), Greenland ice sheet mass balance: Distribution of increased mass loss with climate warming, 2003-07 versus 1992-2002, J. Glaciol., 57, 88-102, doi:10.3189/002214311795306682.

R. C. Bales, Sierra Nevada Research Institute, University of California, Merced, CA 95343, USA.

G. Bigg and E. Hanna, Department of Geography, University of Sheffield, Winter St., Sheffield S10 2TN, UK. (ehanna@sheffield.ac.uk)

E. Burgess, Department of Geography, University of Utah, Salt Lake City, UT 84112, USA.

J. Cappelen, Weather and Climate Information Division, Danish Meteorological Institute, Lyngbyvej 100, DK-2100 Copenhagen, Denmark. M. Griffiths and D. Savas, Corporate Information and Computing Services, University of Sheffield, Western Bank, Sheffield S10 2TN, UK

P. Huybrechts, Earth System Sciences, Vrije Universiteit, B-1050 Brussels, Belgium.

J. R. McConnell, Desert Research Institute, Reno, NV 89512, USA.

K. Steffen, Cooperative Institute for Research in Environmental Sciences, University of Colorado, Boulder, CO 80309, USA.

J. P. Steffensen, Department of Geophysics, University of Copenhagen, Juliane Maries Vej 30, DK-2100 Copenhagen, Denmark.

M. Van den Broeke, Institute for Marine and Atmospheric Research Utrecht, Utrecht University, P.O. Box 80.005, NL-3508 TA Utrecht Netherlands.

L. Wake, Department of Geography, University of Calgary, Calgary, AB T2N 1N4, Canada. 